\title{
Synthesis, Crystal Structures, Thermal and Antimicrobial Properties of Mn(II) Complexes of 1,10-Phenanthroline With Some Co-Ligands
}

\author{
Donatus Bekindaka Eni ${ }^{1}$, Divine Mbom Yufanyi ${ }^{2}$, Che Dieudonne Tabong ${ }^{3}$, Rajamony Jagan ${ }^{4}$, Moise Ondoh Agwara ${ }^{4}$ \\ ${ }^{1}$ Department of Inorganic Chemistry, University of Yaounde I, P.O. Box 812 Yaounde, Cameroon \\ ${ }^{2}$ Department of Chemistry, Faculty of Science, The University of Bamenda, P.O. Box 39 Bambili, Cameroon \\ ${ }^{3}$ Department of Chemistry, Higher Teachers' Training College Bambili, The University of Bamenda, Cameroon \\ ${ }^{4}$ Sophisticated Analytical Instruments Facility, Indian Institute of Technology, Chennai-600036, Madras, India \\ Correspondence: Moise Ondoh Agwara, Department of Inorganic Chemistry, University of Yaounde I, P.O. Box 812 \\ Yaounde, Cameroon. Tel: (+237)679 875245 E-mail: agwara29@yahoo.com
}

Received: November 9, 2018 Accepted: November 27, 2018 Online Published: November 28, 2018

doi:10.5539/ijc.v10n4p155

URL: https://doi.org/10.5539/ijc.v10n4p155

\begin{abstract}
The complexes of Manganese(II) with 1,10-phenanthroline using the nitrate, azide and dicyanamide as co-ligands have been synthesized and characterized by elemental analysis, infrared spectroscopy, thermal analysis and room temperature magnetic susceptibility measurements. The magnetic moments of the complexes are consistent with high spin $\left(\mathrm{d}^{5}\right)$ octahedral geometry. Single-crystal X-ray analysis confirmed the complexes to be $\left[\mathrm{Mn}(\mathrm{Phen})_{2}\left(\mathrm{NO}_{3}\right)_{2}\right](\mathbf{1})$, $\left.\left[\mathrm{Mn}(\mathrm{Phen})_{2}\left(\mathrm{~N}_{3}\right)_{2}\right)\right](\mathbf{2})$, and $\left.\left[\mathrm{Mn}(\mathrm{Phen})_{2}(\mathrm{dca})_{2}\right)\right](\mathbf{3})$. Complexes $\mathbf{1}$ and $\mathbf{2}$ crystallize in an orthorhombic crystal system with space group $P b c n$ while complex 3 crystallizes in the monoclinic crystal system with space group $P 2_{1} / c$. The complexes have been screened for in vitro antibacterial and antifungal activities by the disc diffusion method. The minimum inhibitory concentration values indicate that the complexes showed greater activity against the fungi strains tested compared to that of the reference antifungal.
\end{abstract}

Keywords: antimicrobial properties, azide; dicyanamide, manganese(II), 1,10-phenanthroline, X-ray crystal structure

\section{Introduction}

Recently, there has been sustained interest in the coordination chemistry of 1,10-phenanthroline (Bencini and Lippolis 2010). Its unique physical and chemical properties coupled with its coordination ability, makes it suitable for various applications. For example, these complexes have potential technological applications due to their ability to absorb strongly in the the ultraviolet spectral region, emit bright light alongside their good electro- and photoactive properties (Bencini and Lippolis 2010). 1,10-Phenanthroline (phen) is also a biologically important ligand which, together with some of its metal complexes, has been shown to be effective against various strains of microorganisms (McCann, Geraghty et al. 2000, Agwara, Ndifon et al. 2010, Aljahdali and El-Sherif 2013, Colak, Oztopcu-Vatan et al. 2013).) This rigid, planar framework and versatile polypyridine nitrogen donor ligand 1,10-Phenanthroline (phen), has been extensively studied for its coordination ability (scheme 1) and stability in biochemical processes. Due to the chelating nature of phenanthroline and substituted phenanthroline ligands in metal complexes, they control the supramolecular assemblies formed through chelation of the metal center (Bencini and Lippolis 2010). 


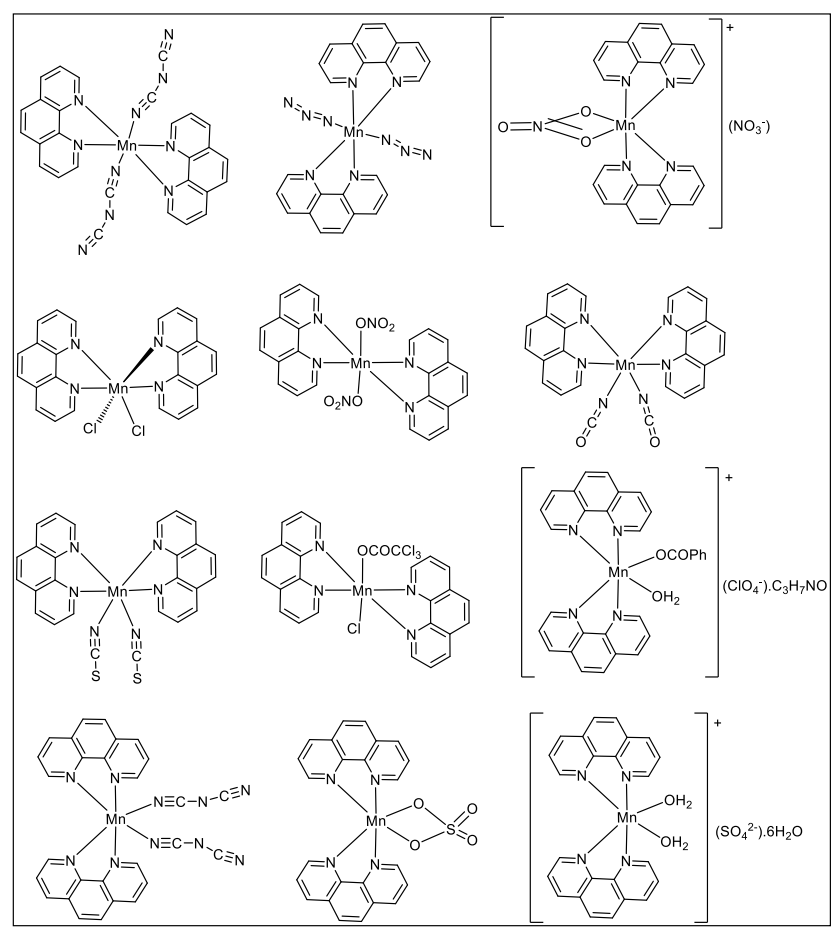

Scheme 1. Some complexes of Mn-Phen found in the literature

The potential of mixed ligand complexes with 1,10-phen as models for biological systems, such as binding of small molecules to DNA, has attracted scientific interest (Jennifer and Muthiah 2014). Interest is also focused on the the ability of 1,10-phen to use its extended $\pi$-system to form non-covalent $\pi$-interactions, which mimic various biological processes (Jennifer and Muthiah 2014, Pook, Hentrich et al. 2015). The use of mixed ligands having different donor atoms to synthesise complexes, can lead to changes in their physical and chemical properties. Metal complexes of these heterocyclic aromatic ring systems are electron-deficient and can undergo $\pi$ - $\pi$ stacking interactions as $\pi$-acceptors (Pook, Hentrich et al. 2015). Though hydrogen bonding still remains the most reliable and widely used means of enforcing molecular recognition, an interplay of weak intermolecular interactions (offset $\pi$ stacking and $\mathrm{C}-\mathrm{H} \cdots \pi$ interactions) also determines the self-assembly of these molecules into 3D networks (Sun, Tong et al. 2010).

Manganese is an essential trace element and plays an important role in several physiological processes as a constituent or activator of some enzymes. $\mathrm{Mn}(\mathrm{II})$ ion has a $3 \mathrm{~d}^{5}$ outer electronic configuration, with no crystal-field stabilisation energy in its high-spin complexes. No electronic restraints are expected in these high-spin structures. The most common structures of $\mathrm{Mn}(\mathrm{II})$ are therefore those that minimise steric repulsion (octahedral and tetrahedral), some other coordinate (five-coordinate and seven-coordinate) complexes are known in biological systems. Interest in the coordination chemistry of $\mathrm{Mn}$ (II) compounds has increased due to their significant role as redox sites in biological systems such as pyruvate carboxylase, oxaloacetate decarboxylase, superoxide dismutases and diamine oxidases (Wieghardt 1989).

The azide anion exhibits different coordination modes with transition metal ions, leading to a wide variety of fascinating structures (discrete molecules to 3-D arrays) (Chen, Jiang et al. 2009, Lazari, Stamatatos et al. 2009). The coordination modes (Scheme 2a) range from monodentate to bridging bi-, tri- and tetra-dentate (Batten and Murray 2003, Lazari, Stamatatos et al. 2009, Adhikary and Koner 2010). 


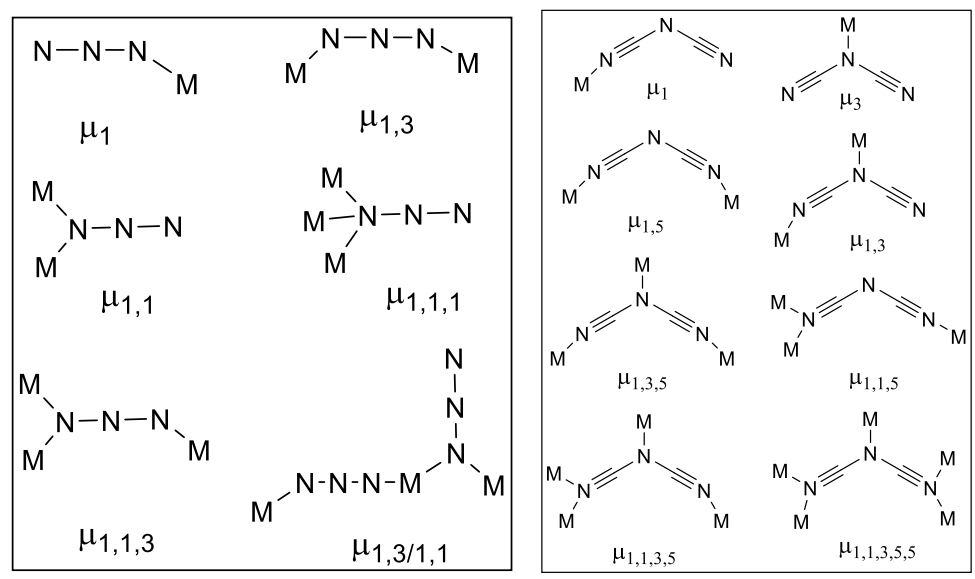

(a)

(b)

Scheme 2. Bonding modes of (a) azide and (b) dicyanamide

The dicyanamide anion shows a variety of different coordination modes (scheme $2 b$ ) which include the terminal and the bridging (Batten and Murray 2003, Mohamadou, van Albada et al. 2003, Sun, Tong et al. 2010).

The nitrate anion in complexes can be a bidentate, bridging, or monodentate ligand or it is as an ionic species. The bonding type is probably a function of the nature and number of other ligands present (Yanick Gaelle, Ondoh Agwara et al. 2017).

One of our research interests is the systematic study of transition metal complexes containing heterocyclic N-donor ligands and other co-ligands (Agwara, Ndifon et al. 2010, Amah, Ondoh et al. 2015, Gaëlle, Yufanyi et al. 2016, Tabong, Yufanyi et al. 2016). The emergence of drug-resistant bacterial and fungal strains has become a public health concern (WHO 2014). This increasing resistance of microbes to antibacterial and antifungal drugs has necessitated the search for new compounds to target these pathogenic microbes (Spellberg, Guidos et al. 2008). Strategies to develop antimicrobial agents to fight against these resistant pathogens include the research and development of new antimicrobial agents (Weinstein and Fridkin 2003, Spellberg, Guidos et al. 2008, Beyth, Houri-Haddad et al. 2015). The modification of biologically active ligands through coordination to metal ions is a possible route for the development of new active agents.

In view of the varied applications of manganese mixed ligand complexes and exploring the good biological and chelating ability of phenanthroline as well as the versatile bonding modes of $\mathrm{dca}^{-}, \mathrm{N}_{3}{ }^{-}$and $\mathrm{NO}_{3}^{-}$, we report herein the synthesis and structure elucidation of three manganese(II) complexes of 1,10-phen and co-ligands. Strong hydrogen bonds and $\pi \cdots \pi$ interactions play important roles in the formation of the 3D structures. The effects of the co-ligands on the biological activities of the complexes towards some resistant pathogens, evaluated using in vitro assays, are also presented.

\section{Method}

All the chemicals were of reagent grade and were used as such without further purification. All solvents used were dried and distilled according to standard methods.

\subsection{Synthesis of the Complexes}

\subsubsection{Synthesis of $\left[\mathrm{Mn}(\mathrm{Phen})_{2}\left(\mathrm{NO}_{3}\right)_{2}\right](\mathbf{1})$}

A $25 \mathrm{~mL}$ methanol solution of $\mathrm{Mn}\left(\mathrm{NO}_{3}\right)_{2} \cdot 4 \mathrm{H}_{2} \mathrm{O}(0.251 \mathrm{~g}, 1 \mathrm{mmol})$ was added drop wise to a $25 \mathrm{~mL}$ methanol solution of 1,10-phenanthroline $(0.396 \mathrm{~g}, 2 \mathrm{mmol})$ with constant stirring and refluxed at $85{ }^{\circ} \mathrm{C}$ for $4 \mathrm{~h}$. The light yellow precipitate obtained was washed with ethanol and the filtrate preserved for crystal growth. Yellow crystals, suitable for single crystal X-ray diffraction, were obtained from the filtrate after two days. The crystals were washed with acetone and then dried in vacuo. Yield: 75\%; anal. Calc.(Found) for $\mathrm{C}_{24} \mathrm{H}_{16} \mathrm{~N}_{6} \mathrm{O}_{6} \mathrm{Mn}$; C:53.45(51.88); H:2.99(2.50); N:15.58(15.57).

2.1.2 Synthesis of $\left[\mathrm{Mn}(\mathrm{Phen})_{2}\left(\mathrm{~N}_{3}\right)_{2}\right]$ (2)

A $25 \mathrm{~mL}$ methanol solution of $\mathrm{Mn}\left(\mathrm{NO}_{3}\right)_{2} \cdot 4 \mathrm{H}_{2} \mathrm{O}(0.251 \mathrm{~g}, 1 \mathrm{mmol})$ was added, drop wise to a $25 \mathrm{~mL}$ methanol solution of 1,10-phenanthroline $(0.396 \mathrm{~g}, 2 \mathrm{mmol})$ with constant stirring and refluxed at $85{ }^{\circ} \mathrm{C}$ for $1 \mathrm{~h}$. After an hour, a $10 \mathrm{~mL}$ water/methanol $(1: 4 \mathrm{v} / \mathrm{v})$ solution of sodium azide $(0.13 \mathrm{~g}, 2 \mathrm{mmol})$ was added drop wise to the mixture and it was further refluxed for $3 \mathrm{~h}$. The intense yellow precipitate obtained was washed with ethanol. Yellow crystals, suitable for 
single crystal X-ray diffraction, were obtained from the filtrate after one day. The crystals were washed with acetone and then dried in vacuo. Yield: 80\%; anal. Calc.(Found) for $C_{24} H_{16} M_{n N} N_{10} ;$ C:57.72(56.65); H:3.23(3.03); $N: 28.05(29.01)$.

\subsubsection{Synthesis of $\left[\mathrm{Mn}(\mathrm{Phen})_{2}(\mathrm{dca})_{2}\right](3)$}

To a $25 \mathrm{~mL}$ methanol solution of $\mathrm{Mn}\left(\mathrm{NO}_{3}\right)_{2} \cdot 4 \mathrm{H}_{2} \mathrm{O}(0.251 \mathrm{~g}, 1 \mathrm{mmol})$ was added, drop wise a $25 \mathrm{~mL}$ methanol solution of 1,10-phenanthroline $(0.396 \mathrm{~g}, 2 \mathrm{mmol})$ with constant stirring and refluxed at $85^{\circ} \mathrm{C}$ for $1 \mathrm{~h}$. After an hour, a $10 \mathrm{~mL}$ water/methanol $(1: 4 \mathrm{v} / \mathrm{v})$ solution of sodium dicyanamide $(0.18 \mathrm{~g}, 2 \mathrm{mmol})$ was added drop wise to the mixture and it was further refluxed for $3 \mathrm{~h}$. The yellow precipitate obtained was washed with ethanol. Light yellow crystals, suitable for single crystal X-ray diffraction, were obtained from the filtrate after one day. The crystals were washed with acetone and then dried in vacuo. Yield: 85\%; anal. Calc.(Found) for $C_{24} H_{16} M_{n N} N_{10} ; C: 61.43(62.29) ; H: 2.95(2.33)$; $N: 25.59(25.92)$.

\subsection{Characterisation}

Elemental analyses $(\mathrm{C}, \mathrm{H}, \mathrm{N})$ of the complexes was carried out on a FLASH 2000 Organic Elemental Analyzer. The melting point/decomposition temperatures of the complexes were obtained using the STUART Scientific Melting Point SMP1 Device with maximum temperature at $360{ }^{\circ} \mathrm{C}$. The FT-IR spectra of the complexes and ligands were recorded from $4000-400 \mathrm{~cm}^{-1}$ on a PerkinElmer Spectrum Two universal attenuated total reflectance Fourier transform infrared (UATR-FT-IR) spectrometer. Thermogravimetric (TG) and differential thermal analysis (DTA) curves were obtained using a NETZSCH STA449F1 thermoanalyzer in a dynamic argon atmosphere (heating rate $10{ }^{\circ} \mathrm{C} \cdot \mathrm{min}^{-1}$, flow rate 25 $\mathrm{mL} / \mathrm{min}$, aluminium oxide crucible, mass $20 \mathrm{mg}$, and temperature range from room temperature up to $900^{\circ} \mathrm{C}$ ). Room temperature magnetic susceptibility measurements of the complexes were determined using the Gouy method with mercury tetrathiocyanocobalt(II) as calibrant on a Stanton Instruments Limited (Model A49).

\subsection{Magnetic Susceptibility Measurement}

Magnetic susceptibility measurements are widely used in studying the magnetic properties of transition metal complexes. The magnetic properties are due to the presence of unpaired electrons in the partially filled d-orbital in the outer shell of these elements. These magnetic measurements give information on the electronic state of the metal ion in the complexes. The magnetic measurements were performed at a temperature range of 5-300 K using a Sherwood Scientific magnetic susceptibility balance. The magnetic data of the samples were obtained by taking the difference in mass between an empty sample tube and the sample tube filled with sample which is in the form of a reasonable fine and uniform powder. The diamagnetic corrections for the samples were estimated using Pascal's constant and the magnetic data were corrected for diamagnetic contributions using sample holder.

The mass susceptibility, $\chi_{\mathrm{g}}$, is calculated using the equation:

$$
\chi_{g}=\frac{C_{B a l} l\left(R-R_{O}\right)}{10^{9} \mathrm{~m}}
$$

Where $1=$ sample length $(\mathrm{cm}) ; \mathrm{m}=$ sample mass $(\mathrm{g}), \mathrm{R}=$ reading for tube plus sample, $\mathrm{R}_{\mathrm{o}}=$ empty tube reading, $\mathrm{C}_{\mathrm{Bal}}=$ balance calibration constant.

\subsection{Single crystal X-ray Data Collection and Structural Refinement}

All intensity data were collected on Bruker AXS Kappa APEX II single crystal CCD Diffractometer, equipped with graphite-monochromated MoK $\alpha$ radiation $(\lambda=0.71073 \AA)$. Data reduction and absorption corrections were performed by APEX2, SAINT-plus and SADABS program (Bruker 2004). The structure was solved by direct methods and the refinement of all non-hydrogen atoms was performed with SHELX97 (Sheldrick 1997). H-atoms were mainly calculated on idealised positions. Structure figures were generated with ORTEP (Farrugia 1997). CCDC 1485344 (1), CCDC 1417782 (2) and CCDC 1485343 (3) contain the supplementary crystallographic data for this paper. These data can be obtained free of charge via www.ccdc.cam.ac.uk/conts/retrieving.html (or from the Cambridge Crystallographic Data Centre, 12 Union Road, Cambridge CB2 1EZ, UK; fax: (+44)1223-336-033; or deposit@ ccdc.cam.uk).

\subsection{Antimicrobial Tests}

The antimicrobial tests were carried out in the Applied Microbiology and Molecular Pharmacology Laboratory (LMP) of the University of Yaoundé I, Cameroon. The tests were done on twenty four pathogenic micro-organisms; twenty bacterial strains: B1=Streptococcus pneumonae ATCC49619, B2=Staphylococcus aureus BAA917, B3=Staphylococcus aureus ATCC43300, B4=Staphylococcus aureus NR45003, B5=Staphylococcus aureus NR46003, B6=Staphylococcus aureus CP7625, B7=Shigella flexineri NR518, B8=Salmonella enterica NR4294, B9=Salmonella enterica NR4311, $\mathrm{B} 10=$ Salmonella enterica NR13555, B11=Pseudomonas aeruginosa NMC592, B12=Klessiella pneumonae ATCC13883, B13=Klessiella pneumonae ATCC70603, B14=Klessiella pneumonae NR41916, B15=Escherishia coli 
ATCC25922, B16=Escherishia coli ATCC35218, B17=Enterococcus fecalis ATCC51219, B18=Staphylococcus aureus NR46374, B19=Hemophyllus influenza ATCC49247, B20 = Mycobacterium smegmatis and four yeasts: Candida krusei, Candida parasilosis, Candida albicans, Cryptococcus neoformans obtained from Centre Pasteur Yaoundé, Cameroon. The selected microorganisms represent the causative agents for diseases that are prevalent in our environment. The microbial isolates were maintained on agar slant at $4^{\circ} \mathrm{C}$ in the laboratory. The strains were sub-cultured on fresh appropriate agar plate in incubators 18 hours prior to any antimicrobial test. Amoxicillin, ciprofloxacin and cloxacillin were used as reference antibiotics (RB) while fluconazole was the reference antifungal (RF).

\subsubsection{Diffusion Tests}

In vitro antimicrobial activity of the ligand, metal salts and complexes were evaluated using the disc-diffusion method as previously described (Gaëlle, Yufanyi et al. 2016, Yanick Gaelle, Ondoh Agwara et al. 2017). The antimicrobial tests were carried out as described by Berghe and Vlietinck (Berghe and Vlietinck 1991). Three replicas were performed for each sample and mean values of the growth inhibition zone were calculated. Compounds with a zone of inhibition IZ $<7$ $\mathrm{mm}$ were considered to be inactive, those in the range $7<\mathrm{IZ}<20 \mathrm{~mm}$ as active and those with $\mathrm{IZ}>20 \mathrm{~mm}$, very active.

\subsubsection{Minimum Inhibitory Concentration of the Complexes}

The Minimum Inhibitory Concentration (MIC) was determined according to National Committee for Clinical Laboratory Standards (NCCLS) M38, a microdilution method using (12 x 8 wells) microtitre plates, as previously described (Sidjui, Toghueo et al. 2016).

\section{Results and Discussion}

Complexes 1-3 were obtained relatively quickly without solvent evaporation. All the complexes are crystalline, coloured and air-stable can be reproducibly prepared in high yields $(>70 \%)$. Their physicochemical properties are summarized in Table 1.

Table 1. Physical data of the complexes

\begin{tabular}{cclccc}
\hline \multicolumn{1}{c}{ Complex } & Nature & Colour & $\begin{array}{c}\text { Yield } \\
(\%)\end{array}$ & $\begin{array}{c}\text { Melting point } \\
\left({ }^{\circ} \mathrm{C}\right)\end{array}$ & $\begin{array}{c}\text { Molar conductivity } \\
\left(\Omega^{-1} \mathrm{~cm}^{2} \mathrm{~mol}^{-1}\right)\end{array}$ \\
\hline$\left[\mathrm{Mn}(\mathrm{Phen})_{2}\left(\mathrm{NO}_{3}\right)_{2}\right](\mathbf{1})$ & Crystals & Yellow & 75 & 356 & 41.36 \\
$\left.\left[\mathrm{Mn}(\mathrm{Phen})_{2}\left(\mathrm{~N}_{3}\right)_{2}\right)\right](\mathbf{2})$ & Crystals & Intense yellow & 80 & $/$ & 23.04 \\
$\left.\left[\mathrm{Mn}(\mathrm{Phen})_{2}(\mathrm{dca})_{2}\right)\right](\mathbf{3})$ & Crystals & Yellow & 85 & 290 & 15.7 \\
\hline
\end{tabular}

Complex 1 melted at $\left(356 \pm 2{ }^{\circ} \mathrm{C}\right)$ while the melting point of the $\left.\left[\mathrm{Mn}(\mathrm{Phen})_{2}\left(\mathrm{~N}_{3}\right)_{2}\right)\right]$ complex could not be determined due to the explosive nature of the azide. Complex $\mathbf{3}$ changed in colour upon heating from yellow to dark orange and then melted at $\left(290 \pm 2{ }^{\circ} \mathrm{C}\right)$. This change in colour is attributed to change in crystal structural geometry from octahedral to tetrahedral as the dca molecules are lost (Allan, Brown et al. 1970, Nagase, Yokobayashi et al. 1976, McCann, Geraghty et al. 2000, Colak, Oztopcu-Vatan et al. 2013). The low molar conductivity values of $41.36 \Omega \mathrm{cm}^{-2} \mathrm{~mol}^{-1}$, $23.04 \Omega \mathrm{cm}^{-2} \mathrm{~mol}^{-1}$ and $15.7 \Omega \mathrm{cm}^{-2} \mathrm{~mol}^{-1}$ in water, for $\mathbf{1}, \mathbf{2}$ and $\mathbf{3}$, respectively, indicates the molecular nature of the complexes. 


\subsection{X-ray Crystal Structure}

The crystallographic data and structure refinement parameters of complexes 1-3 are presented in Table 2.

Table 2. Crystal data and structure refinement parameters for complexes 1-3

\begin{tabular}{|c|c|c|c|}
\hline Complex & 1 & 2 & 3 \\
\hline Chemical formula & $\mathrm{C}_{24} \mathrm{H}_{16} \mathrm{MnN}_{6} \mathrm{O}_{6}$ & $\mathrm{C}_{24} \mathrm{H}_{16} \mathrm{MnN}_{10}$ & $\mathrm{C}_{28} \mathrm{H}_{16} \mathrm{MnN}_{10}$ \\
\hline $\begin{array}{l}\text { Crystal system, space } \\
\text { group }\end{array}$ & Orthorhombic, $P b c n$ & Orthorhombic, $P b c n$ & Monoclinic, $P 2_{1} / c$ \\
\hline Temperature (K) & 296 & 296 & 150 \\
\hline$a, b, c(\AA)$ & $\begin{array}{l}12.5477(14), 10.1607 \\
(10), 17.695(2)\end{array}$ & $\begin{array}{l}13.395(2), \quad 9.6457 \\
(14), 16.979(3)\end{array}$ & $\begin{array}{l}9.8716(8), 14.6636 \\
(8), 17.6165(11)\end{array}$ \\
\hline$\beta\left(^{\circ}\right)$ & & & $104.364(3)$ \\
\hline$V\left(\AA^{3}\right)$ & $2256.0(4)$ & $2193.8(6)$ & $2470.3(3)$ \\
\hline$Z$ & 4 & 4 & 4 \\
\hline Radiation type & Mo $K \alpha$ & Mo $K \alpha$ & Mo $K \alpha$ \\
\hline$\mu\left(\mathrm{mm}^{-1}\right)$ & 0.64 & 0.64 & 0.57 \\
\hline Crystal size $(\mathrm{mm})$ & $0.30 \times 0.25 \times 0.25$ & $0.25 \times 0.25 \times 0.20$ & $0.17 \times 0.16 \times 0.13$ \\
\hline$T_{\min }, T_{\max }$ & $0.831,0.856$ & $0.861,0.941$ & $0.847,0.867$ \\
\hline $\begin{array}{l}\text { No. of measured, } \\
\text { independent and } \\
\text { observed }[I>2 \sigma(I)] \\
\text { reflections }\end{array}$ & $12206,2957,1774$ & $22275,2029,1349$ & $54213,6160,4835$ \\
\hline$R_{\mathrm{int}}$ & 0.026 & 0.041 & 0.056 \\
\hline$(\sin \theta / \lambda)_{\max }\left(\AA^{-1}\right)$ & 0.703 & 0.606 & 0.668 \\
\hline $\begin{array}{l}R\left[F^{2}>\quad 2 \sigma\left(F^{2}\right)\right], \\
w R\left(F^{2}\right), S\end{array}$ & $0.058,0.187,1.02$ & $0.077,0.179,1.17$ & $0.036,0.085,1.06$ \\
\hline No. of reflections & 2957 & 2029 & 6160 \\
\hline No. of parameters & 168 & 159 & 352 \\
\hline No. of restraints & 0 & 0 & 0 \\
\hline $\mathrm{H}$-atom treatment & $\begin{array}{l}\text { H-atom parameters } \\
\text { constrained }\end{array}$ & $\begin{array}{l}\text { H-atom parameters } \\
\text { constrained }\end{array}$ & $\begin{array}{l}\text { H-atom parameters } \\
\text { constrained }\end{array}$ \\
\hline$\Delta \rho_{\max }, \Delta \rho_{\min }\left(\mathrm{e} \AA^{-3}\right)$ & $0.67,-0.55$ & $0.71,-0.52$ & $0.37,-0.39$ \\
\hline
\end{tabular}

\subsubsection{Crystal Structure of $\left[\mathrm{Mn}(\mathrm{Phen})_{2}\left(\mathrm{NO}_{3}\right)_{2}\right](\mathbf{1})$}

Complex 1 crystallizes in the orthorhombic crystal system with space group Pbcn with four molecules in the unit cell. The ORTEP representation of the crystal structure is shown in Figure 1 and the packing diagram in Figure 2. Selected bond lengths and angles are presented in Table 3 while the H-bond parameters are given in Table 4. The asymmetric unit of complex 1 consists of one phenanthroline molecule, one nitrate ion and one $\mathrm{Mn}$ (II) ion and the other half of the asymmetric unit is generated by inversion symmetry. The $\mathrm{Mn}$ (II) ion is coordinated by four $\mathrm{N}$ atoms from two chelating phen ligands and two $\mathrm{O}$ atoms from two nitrate ions giving a $\mathrm{MnN}_{4} \mathrm{O}_{2}$ coordination sphere with a distorted octahedral geometry. Three phen $\mathrm{N}$ atoms [N(1)-Mn(1) 2.319(3) $\mathrm{A}, \mathrm{N}(2)-\mathrm{Mn}(1) 2.289$ (3) $\AA, \operatorname{Mn}(1)-\mathrm{N}(2) \# 1$ 2.289(3) $⿱$ ] $]$ and one nitrate $\mathrm{O}$ atom $[\mathrm{O}(1)-\mathrm{Mn}(1) 2.422(6) \AA]$ form the equatorial plane, whereas symmetry related fourth phen $\mathrm{N}$ atom $[\mathrm{Mn}(1)-\mathrm{N}(1) \# 1$ 2.319(3)] and the second nitrate ion [Mn(1)-O(1)\#1 2.422(7)] are in apical positions. The $\mathrm{N}(2)-\mathrm{Mn}(1)-\mathrm{N}(1) \# 1$ bond angle of $88.70(10)^{\circ}$ indicates that the $\mathrm{N}(2)-\mathrm{Mn}(1)$ and $\mathrm{Mn}(1)-\mathrm{N}(1) \# 1$ bonds are in different planes, almost perpendicular to each other. The 5-membered chelating rings of $\mathrm{Mn}(\mathrm{II})$ and $\mathrm{N}$ atoms of phen exhibit a near perfect plane; the $\mathrm{N} 2-\mathrm{C} 11-\mathrm{C} 12-\mathrm{N} 1$ torsion angle is $0.84(4)^{\circ}$ for complex $\mathbf{1}$. The $\mathrm{Mn}-\mathrm{N}$ bond lengths are in the range 2.289(3)-2.319(3) $\AA$, which are similar to values reported in the literature (Ma, Wang et al. 2001, Kani, Atlier et 
al. 2016). The $\mathrm{N}(2)-\mathrm{Mn}(1)-\mathrm{N}(1)$ chelating angle is $72.14(10)^{\circ}$. The bond lengths in the phenanthroline ring range from $1.328(6)-1.438(4) \AA$ in $\mathrm{C}-\mathrm{C}$ and from 1.323(4)-1.352(4) $\AA$ in $\mathrm{C}-\mathrm{N}$ and this is similar to literature reported values for phenanthroline complexes (Ma, Wang et al. 2001, Kani, Atlier et al. 2016).

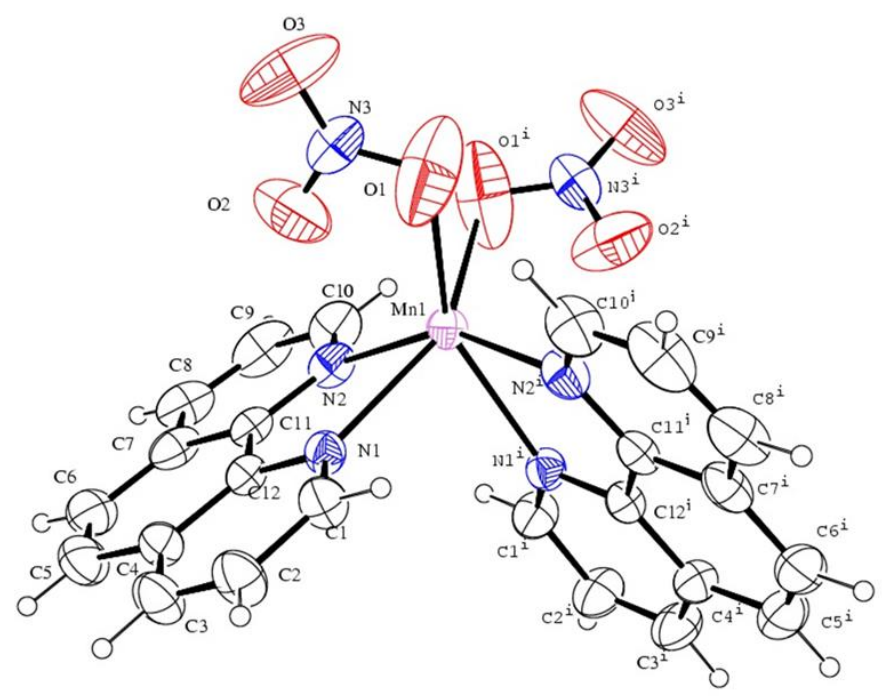

Figure 1. ORTEP view of the crystal structure of [dinitrato-bis(1,10-phenanthroline- $\left.\kappa^{2} N, N^{\prime}\right)$ manganese(II) (1)

The packing in the unit cell is based on intermolecular hydrogen bonding and $\pi-\pi$ stacking interactions. Cooperation between extensive series of $\mathrm{C}-\mathrm{H} \cdots \mathrm{O}$ hydrogen bonds (Čechová, Martišková et al. 2014, Hu and Zhang 2016) (Table 4) and face-to-face $\pi-\pi$ [C9-C4 3.369(6) $\AA$; symmetry code $-1 / 2+\mathrm{x},-1 / 2+\mathrm{y}, 3 / 2-\mathrm{z}]$ stacking interactions (Janiak 2000), between adjacent phen ligands, stabilize the structure and assemble complex 1 into an interesting 3D supramolecular structure. It is noteworthy to mention that a polymorph of $\mathbf{1}$ is known (Saphu, Chanthee et al. 2012). The comparative crystal data of the complexes are presented in Table 5.

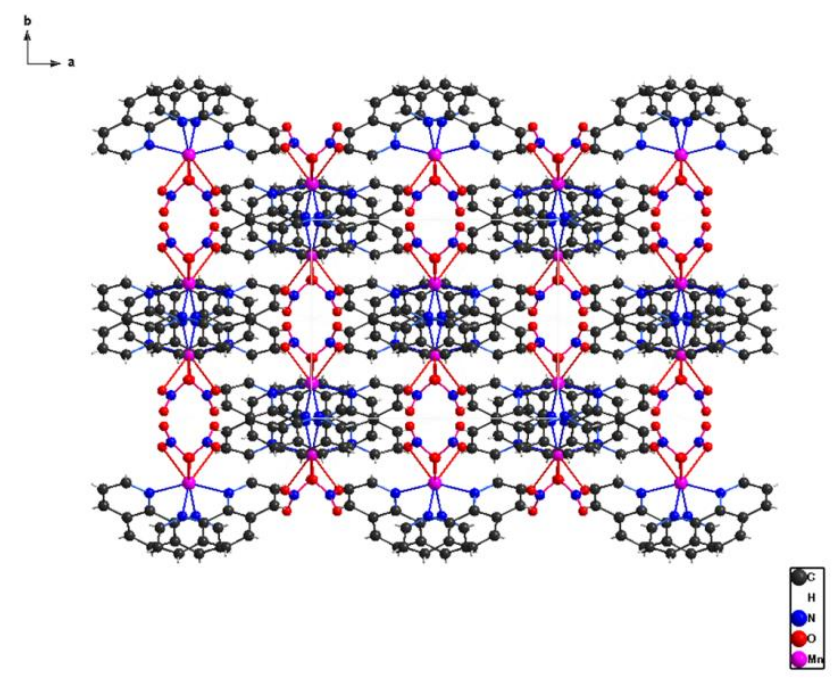

Figure 2. Packing diagram of $\mathbf{1}$ seen along the crystallographic c-axis 
Table 3. Selected bond lengths and bond angles for complex 1

\begin{tabular}{llll}
\hline Bond & Length $(\AA)$ & Bond & Angle $\left(^{\circ}\right)$ \\
\hline $\mathrm{N}(1)-\mathrm{Mn}(1)$ & $2.319(3)$ & $\mathrm{O}(3)-\mathrm{N}(3)-\mathrm{O}(2)$ & $123.8(5)$ \\
$\mathrm{N}(2)-\mathrm{Mn}(1)$ & $2.289(3)$ & $\mathrm{O}(3)-\mathrm{N}(3)-\mathrm{O}(1)$ & $126.7(6)$ \\
$\mathrm{N}(3)-\mathrm{O}(3)$ & $1.155(4)$ & $\mathrm{O}(2)-\mathrm{N}(3)-\mathrm{O}(1)$ & $109.3(5)$ \\
$\mathrm{N}(3)-\mathrm{O}(2)$ & $1.195(5)$ & $\mathrm{N}(3)-\mathrm{O}(1)-\mathrm{Mn}(1)$ & $103.6(4)$ \\
$\mathrm{N}(3)-\mathrm{O}(1)$ & $1.203(5)$ & $\mathrm{N}(3)-\mathrm{O}(2)-\mathrm{Mn}(1)$ & $100.0(4)$ \\
$\mathrm{O}(1)-\mathrm{Mn}(1)$ & $2.422(6)$ & $\mathrm{N}(2) \# 1-\mathrm{Mn}(1)-\mathrm{N}(2)$ & $153.72(15)$ \\
$\mathrm{O}(2)-\mathrm{Mn}(1)$ & $2.495(6)$ & $\mathrm{N}(2) \# 1-\mathrm{Mn}(1)-\mathrm{N}(1) \# 1$ & $72.14(10)$ \\
$\mathrm{Mn}(1)-\mathrm{N}(2) \# 1$ & $2.289(3)$ & $\mathrm{N}(2)-\mathrm{Mn}(1)-\mathrm{N}(1) \# 1$ & $88.70(10)$ \\
$\mathrm{Mn}(1)-\mathrm{N}(1) \# 1$ & $2.319(3)$ & $\mathrm{N}(2) \# 1-\mathrm{Mn}(1)-\mathrm{N}(1)$ & $88.70(10)$ \\
$\mathrm{Mn}(1)-\mathrm{O}(1) \# 1$ & $2.422(7)$ & $\mathrm{N}(2)-\mathrm{Mn}(1)-\mathrm{N}(1)$ & $72.14(10)$ \\
$\mathrm{Mn}(1)-\mathrm{O}(2) \# 1$ & $2.495(6)$ & $\mathrm{N}(1) \# 1-\mathrm{Mn}(1)-\mathrm{N}(1)$ & $87.09(14)$ \\
$\mathrm{C}(10)-\mathrm{H}(10)$ & 0.9300 & $\mathrm{~N}(2) \# 1-\mathrm{Mn}(1)-\mathrm{O}(1) \# 1$ & $122.84(14)$ \\
$\mathrm{C}(11)-\mathrm{N}(2)$ & $1.352(4)$ & $\mathrm{N}(2)-\mathrm{Mn}(1)-\mathrm{O}(1) \# 1$ & $78.61(15)$ \\
$\mathrm{C}(11)-\mathrm{C}(12)$ & $1.438(4)$ & $\mathrm{N}(1) \# 1-\mathrm{Mn}(1)-\mathrm{O}(1) \# 1$ & $104.40(18)$ \\
$\mathrm{C}(12)-\mathrm{N}(1)$ & $1.351(4)$ & $\mathrm{N}(1)-\mathrm{Mn}(1)-\mathrm{O}(1) \# 1$ & $148.31(14)$ \\
$\mathrm{C}(5)-\mathrm{C}(6)$ & $1.328(6)$ & $\mathrm{N}(2) \# 1-\mathrm{Mn}(1)-\mathrm{O}(1)$ & $78.61(15)$ \\
\hline
\end{tabular}

Table 4. Hydrogen-bond geometry $\left(\AA,^{\circ}\right)$ for (1)

\begin{tabular}{lllll}
\hline$D-\mathrm{H} \cdots A$ & $D-\mathrm{H}$ & $\mathrm{H} \cdots A$ & $D \cdots A$ & $D-\mathrm{H} \cdots A$ \\
\hline $\mathrm{C} 10-\mathrm{H} 10 \cdots \mathrm{O}^{\mathrm{i}}$ & 0.93 & 2.34 & $2.935(8)$ & 122 \\
$\mathrm{C} 3-\mathrm{H} 3 \cdots \mathrm{O} 2^{\text {ii }}$ & 0.93 & 2.65 & $3.460(6)$ & 144.1 \\
$\mathrm{C} 6-\mathrm{H} 6 \cdots{ }^{\text {iii }}$ & 0.931 & 2.719 & $3.394(7)$ & 130.1 \\
$\mathrm{C} 6-\mathrm{H} 6 \cdots{ }^{\text {iv }}{ }^{\text {iv }}$ & 0.931 & 2.579 & $3.381(5)$ & 144.5
\end{tabular}

Symmetry code: (i) $-\mathrm{x}, \mathrm{y},-\mathrm{z}+3 / 2$; (ii) $-\mathrm{x},-\mathrm{y}, 1-\mathrm{z}$; (iii) $-1 / 2+\mathrm{x}, 1 / 2-\mathrm{y}, 1-\mathrm{z} ; \quad$ (iv) $-1 / 2+\mathrm{x},-1 / 2+\mathrm{y}, 3 / 2-\mathrm{z}$

Table 5. Comparative crystal data of $\mathbf{1}$ with that of a known polymorph

\begin{tabular}{lll}
\hline Complex & \multicolumn{1}{c}{$\mathbf{1}$ (this work) } & {$\left[\mathrm{Mn}\left(\mathrm{NO}_{3}\right)_{2}\left(\mathrm{C}_{12} \mathrm{H}_{8} \mathrm{~N}_{2}\right)_{2}\right]$ (Saphu, Chanthee et al. 2012) } \\
\hline Chemical formula & $\mathrm{C}_{24} \mathrm{H}_{16} \mathrm{MnN}_{6} \mathrm{O}_{6}$ & $\mathrm{C}_{24} \mathrm{H}_{16} \mathrm{MnN}_{6} \mathrm{O}_{6}$ \\
$M_{\mathrm{r}}$ & 539.37 & 539.37 \\
Crystal system, space group & Orthorhombic, Pbcn & Monoclinic, C2/c \\
Temperature (K) & 296 & 298 \\
$a$ & $12.5477(14)$ & $11.6191(6)$ \\
$b$ & $10.1607(10)$ & $15.1164(8)$ \\
$c$ & $17.695(2)$ & $13.4526(7)$ \\
$\beta\left({ }^{\circ}\right)$ & 90 & $105.387(1)$ \\
$V\left(\AA^{3}\right)$ & $2256.0(4)$ & $2278.1(2)$ \\
$Z$ & 4 & 4 \\
\hline
\end{tabular}

3.1.2 Crystal Structure of $\left.\left[\mathrm{Mn}(\mathrm{Phen})_{2}\left(\mathrm{~N}_{3}\right)_{2}\right)\right](2)$

Complex 2 crystallizes in the orthorhombic crystal system with space group Pbcn with four molecules in the unit cell. The ORTEP representation of the crystal structure is shown in Figure 3 and the packing diagram in Figure 4. Selected bond lengths and angles are presented in Table 6 while the H-bond parameters are given in Table 7. The asymmetric unit consists of one molecule of phen, one azide anion, one $\mathrm{Mn}$ (II) ion and the other half of the asymmetric unit is generated by inversion symmetry. Chemically, each $\mathrm{Mn}$ atom is six-coordinate with four $\mathrm{N}$ atoms of two phen

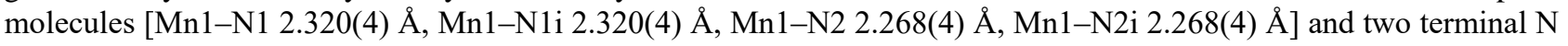


atoms from two azide anions [Mn1-N3 2.130(6) $\AA$, Mn1-N3i 2.130(6) $\AA$ ] giving a distorted octahedral geometry around the Mn atom with MnN6 chromophore. The azido ligands have a cis configuration in the structure. This observation is similar to literature reports of the same structure obtained by different synthetic methods but with slightly different crystal parameters (Shen, Zuo et al. 1999, Masárová and Moncol 2016).

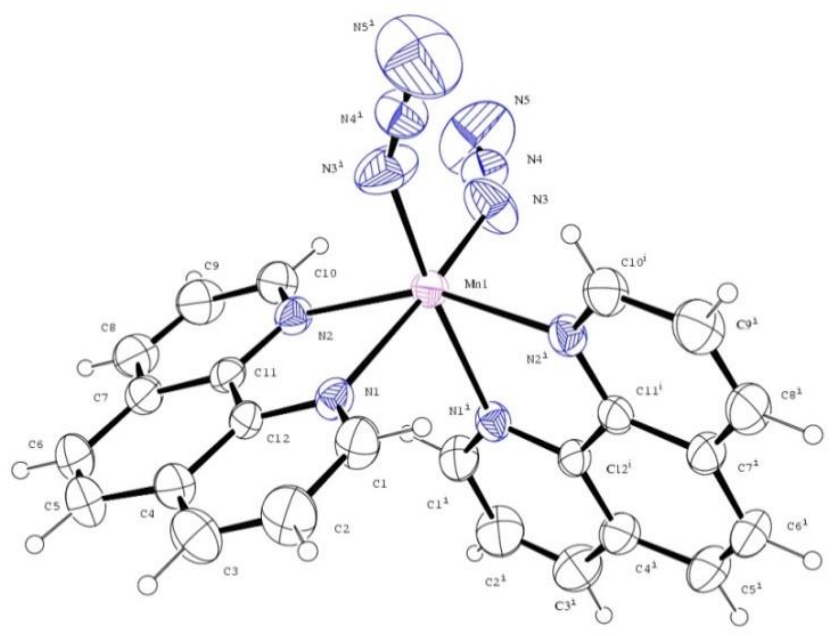

Figure 3. ORTEP view of crystal structure of [diazido-bis(1,10-phenanthroline- $\left.\kappa^{2} N, N^{\prime}\right)$ manganese(II) (2)

Table 6. Selected bond lengths and angles for 2

\begin{tabular}{llll}
\hline Bond & Length $(\AA)$ & Bond & Angle $\left(^{\circ}\right)$ \\
\hline Mn1-N3 & $2.130(6)$ & N3-Mn1-N3 & $97.9(4)$ \\
Mn1-N3 $^{\mathrm{i}}$ & $2.130(6)$ & N3-Mn1-N2 & $101.1(2)$ \\
Mn1-N2 $^{\mathrm{i}}$ & $2.268(4)$ & N3i-Mn1-N2 & $95.7(2)$ \\
Mn1-N2 & $2.268(4)$ & N3-Mn1-N2 & $95.7(2)$ \\
Mn1-N1 & $2.320(4)$ & N3i-Mn1-N2 & $101.1(2)$ \\
Mn1-N1 & $2.320(4)$ & N2i-Mn1-N2 & $154.3(2)$ \\
N1-C1 & $1.323(6)$ & N3-Mn1-N1 & $88.8(2)$ \\
C4-C5 & $1.425(9)$ & N3i-Mn1-N1 & $167.17(19)$ \\
N1-C12 & $1.347(6)$ & N2i-Mn1-N1 & $72.16(16)$ \\
C6-C5 & $1.329(10)$ & N2-Mn1-N1 & $89.03(15)$ \\
N2-C10 & $1.325(7)$ & N3-Mn1-N1 & $167.17(19)$ \\
& & N1i-Mn1-N1 & $86.8(2)$ \\
& & N5-N4-N3 & $178.8(9)$ \\
\hline
\end{tabular}

The axial positions are occupied by the $\mathrm{N} 3^{\mathrm{i}}$ from one azide and $\mathrm{N} 1^{\mathrm{i}}$ from a phen molecule $\quad\left[\mathrm{N} 3^{\mathrm{i}}-\mathrm{Mn} 1-\mathrm{N} 1^{\mathrm{i}} 167.17(19)^{\circ}\right]$ while the equatorial plane is formed by the coordinating atoms $\mathrm{N} 1, \mathrm{~N} 2$ from one phen molecule, $\mathrm{N} 2{ }^{\mathrm{i}}$ from the second phen molecule and $\mathrm{N} 3$ from an azide ion. The bond angles in the equatorial plane deviate noticeably from the ideal value of $90^{\circ}$, with two larger, 101.1(2) ${ }^{\circ}$ for $\mathrm{N} 3-\mathrm{Mn} 1-\mathrm{N} 2^{\mathrm{i}}, 95.7(2)^{\circ}$ for $\mathrm{N} 3-\mathrm{Mn} 1-\mathrm{N} 2$ and two smaller angles of $89.03(15)^{\circ}$ for $\mathrm{N} 2^{\mathrm{i}}-\mathrm{Mn} 1-\mathrm{N} 1$ and $72.16(16)^{\circ}$ for $\mathrm{N} 2-\mathrm{Mn} 1-\mathrm{N} 1$. This deviation in bond angles coupled with the observation that the $\mathrm{Mn}-\mathrm{N}_{\text {(azide) }}$ bonds are slightly shorter than the $\mathrm{Mn}-\mathrm{N}_{(\text {phen) }}$ bonds indicate a highly distorted square-planar arrangement in the equatorial plane. There are two long $\mathrm{Mn}-\mathrm{N}_{(\text {phen) }}$ bonds [Mn1-N1 2.320(4) $\AA$ ] and two short ones [Mn1-N2 2.268(4) $\AA$ ]. Each of the phen ligands forms a five-membered chelate ring with Mn. They are almost planar [torsion angle N2-C11-C12-N1 is $-0.8(7)^{\circ}$ ] and are oriented in two different molecular planes (Shen, Zuo et al. 1999, Zhang, Chen et al. 2002, Čechová, Martišková et al. 2014). The N5-N4-N3 bond angle of 178.8 (9) ${ }^{\circ}$ indicates that the azide anion is almost linear. The $\mathrm{C} 8-\mathrm{H} 8 \cdots \mathrm{N} 3 \mathrm{H}$-bonds between the nitrogen atom of an azide ion and 
one phenanthroline ligand coupled with $\pi-\pi$ stacking interactions between the phen ring systems are observed and consolidate an extensive three-dimensional supramolecular network.

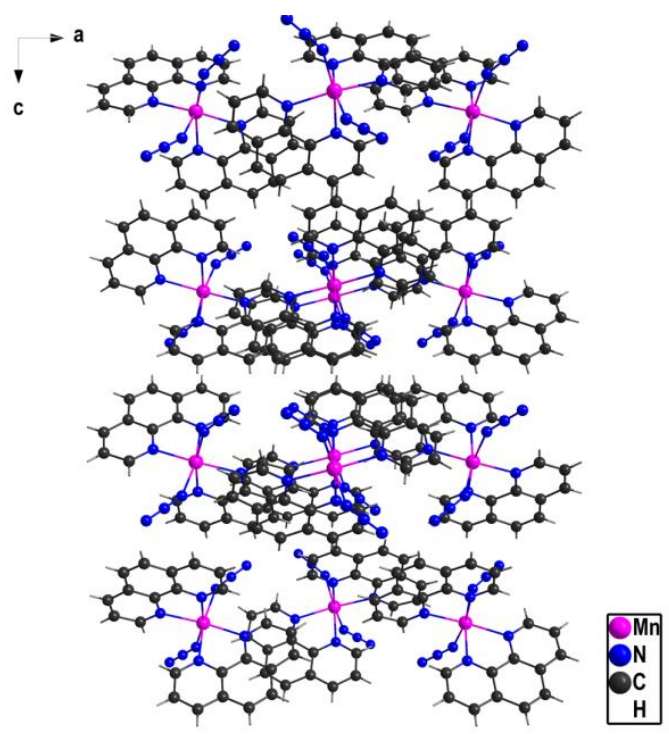

Figure 4. Packing diagram of $\mathbf{2}$ seen along the crystallographic b-axis showing

Table 7. Hydrogen-bond geometry for $\mathbf{2}\left(\AA{ }^{\circ}\right)$

\begin{tabular}{lllll}
\hline$D-\mathrm{H} \cdots A$ & $D-\mathrm{H}$ & $\mathrm{H} \cdots A$ & $D \cdots A$ & $D-\mathrm{H} \cdots A$ \\
\hline $\mathrm{C} 8-\mathrm{H} 8 \cdots \mathrm{N} 3$ & 0.931 & 2.552 & $3.342(8)$ & 143 \\
\hline
\end{tabular}

\subsubsection{Crystal Structure Of $\left.\left[\mathrm{Mn}(\mathrm{Phen})_{2}(\mathrm{dca})_{2}\right)\right](\mathbf{3})$}

Complex 3, bis(dicyanamido)bis(1,10-phenanthroline)manganese(II), crystallizes in the monoclinic crystal system with space group $P 2_{1} / c$ with four molecules in the unit cell. The ORTEP view of the crystal structure together with the atom numbering scheme used in the corresponding tables are shown in Figure 5 and the crystal packing diagram seen along the crystallographic $b$-axes is shown in Figure 6. Selected bond lengths and angles are presented in Table 8 while the $\mathrm{H}$-bond parameters are given in Table 9.

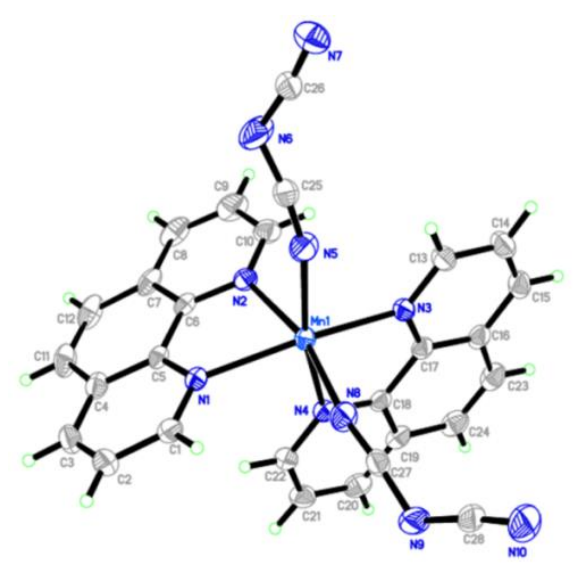

Figure 5. ORTEP view of crystal structure of $\mathbf{3}$

The asymmetric unit consists of two 1,10-phenanthroline molecules, two monodentate non-bridging dicyanamido anions, and one $\mathrm{Mn}(\mathrm{II})$ ion. A similar structure with slightly different parameters, obtained by a 1:1:1 reaction of $\mathrm{Mn}(\mathrm{OAc})_{2} \cdot 4 \mathrm{H}_{2} \mathrm{O}, \mathrm{Na}(\mathrm{dca})$, and o-phen in an ethanol/water mixture, has been reported (Wang, Luo et al. 2000). Chemically, each manganese atom is six-coordinate; bonded to four $\mathrm{N}$-atoms of two phen molecules [Mn1-N1

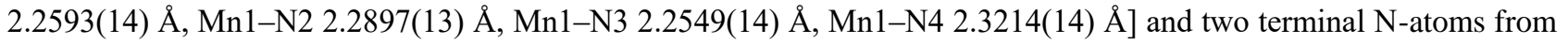


two dicyanamide anions [Mn1-N5 2.1505(16) $\AA$, Mn1-N8 2.1552(15) $\AA$ ] giving a distorted octahedral geometry around the $\mathrm{Mn}$ atom with $\mathrm{MnN}_{6}$ chromophore. The axial positions are occupied by the $\mathrm{N} 2$ atom of one phen ring and the $\mathrm{N} 8$ atom of one azide ion $\left[\mathrm{N}(8)-\mathrm{Mn}(1)-\mathrm{N}(2) \quad 165.68(5)^{\circ}\right]$ while the equatorial plane is formed by the coordinating atoms N1, N3, N4 from two different phen molecules and N5 from the another dicyanamide anion. The $\mathrm{Mn}-\mathrm{N}($ phen) $[2.2549(14)-2.3214(14) \AA]$ and the $\mathrm{Mn}-\mathrm{N}(\mathrm{dca})[2.1505(16)-2.1552(15) \AA]$ are in agreement with values reported in the literature (Wang, Luo et al. 2000, Manson, Brown et al. 2013). The longer Mn-N(phen) bonds [Mn(1) $\mathrm{N}(2)$ 2.2897(13), $\mathrm{Mn}(1)-\mathrm{N}(4) 2.3214(14)]$ are trans to each other [N(2)-Mn(1)-N(4) 85.19(5) $]$. The $\mathrm{N}(5)-\mathrm{Mn}(1)-\mathrm{N}(8)$ bond angle of $98.21(6) 2(6)^{\circ}$ indicates that the Mn1-N5 and N8-Mn1 bonds are in two different molecular planes almost perpendicular to each other. The dicyanamido anions do not coordinate linearly [N8-C27-N9 173.4(2) ${ }^{\circ}$, N5C25-N6 $\left.171.7(2)^{\circ}\right]$ to the metal centre as observed in other Mn-dca complexes (Wang, Luo et al. 2000, Manson, Brown et al. 2013). The two phen ligands which form five-membered chelate rings with $\mathrm{Mn}$ are oriented in two different molecular planes.

Table 8. Selected Bond lengths $(\AA)$ and angles $\left(^{\circ}\right)$ for $\mathbf{3}$

\begin{tabular}{llll}
\hline Bond & Length $(\AA)$ & Bond & Angle $\left(^{\circ}\right)$ \\
\hline $\mathrm{Mn}(1)-\mathrm{N}(5)$ & $2.1505(16)$ & $\mathrm{N}(5)-\mathrm{Mn}(1)-\mathrm{N}(8)$ & $98.21(6)$ \\
$\mathrm{Mn}(1)-\mathrm{N}(8)$ & $2.1552(15)$ & $\mathrm{N}(5)-\mathrm{Mn}(1)-\mathrm{N}(3)$ & $93.37(6)$ \\
$\mathrm{Mn}(1)-\mathrm{N}(3)$ & $2.2549(14)$ & $\mathrm{N}(8)-\mathrm{Mn}(1)-\mathrm{N}(3)$ & $98.65(5)$ \\
$\mathrm{Mn}(1)-\mathrm{N}(1)$ & $2.2593(14)$ & $\mathrm{N}(5)-\mathrm{Mn}(1)-\mathrm{N}(1)$ & $104.32(6)$ \\
$\mathrm{Mn}(1)-\mathrm{N}(2)$ & $2.2897(13)$ & $\mathrm{N}(8)-\mathrm{Mn}(1)-\mathrm{N}(1)$ & $93.31(5)$ \\
$\mathrm{Mn}(1)-\mathrm{N}(4)$ & $2.3214(14)$ & $\mathrm{N}(3)-\mathrm{Mn}(1)-\mathrm{N}(1)$ & $157.00(5)$ \\
$\mathrm{N}(3)-\mathrm{C}(13)$ & $1.328(2)$ & $\mathrm{N}(5)-\mathrm{Mn}(1)-\mathrm{N}(2)$ & $89.05(6)$ \\
$\mathrm{N}(3)-\mathrm{C}(17)$ & $1.361(2)$ & $\mathrm{N}(8)-\mathrm{Mn}(1)-\mathrm{N}(2)$ & $165.68(5)$ \\
$\mathrm{N}(4)-\mathrm{C}(22)$ & $1.331(2)$ & $\mathrm{N}(3)-\mathrm{Mn}(1)-\mathrm{N}(2)$ & $93.19(5)$ \\
$\mathrm{N}(4)-\mathrm{C}(18)$ & $1.360(2)$ & $\mathrm{N}(1)-\mathrm{Mn}(1)-\mathrm{N}(2)$ & $72.87(5)$ \\
$\mathrm{N}(5)-\mathrm{C}(25)$ & $1.152(2)$ & $\mathrm{N}(5)-\mathrm{Mn}(1)-\mathrm{N}(4)$ & $164.65(6)$ \\
$\mathrm{N}(6)-\mathrm{C}(25)$ & $1.286(3)$ & $\mathrm{N}(8)-\mathrm{Mn}(1)-\mathrm{N}(4)$ & $90.62(6)$ \\
$\mathrm{N}(6)-\mathrm{C}(26)$ & $1.307(3)$ & $\mathrm{N}(3)-\mathrm{Mn}(1)-\mathrm{N}(4)$ & $72.81(5)$ \\
$\mathrm{N}(7)-\mathrm{C}(26)$ & $1.156(2)$ & $\mathrm{N}(1)-\mathrm{Mn}(1)-\mathrm{N}(4)$ & $87.57(5)$ \\
$\mathrm{N}(8)-\mathrm{C}(27)$ & $1.155(2)$ & $\mathrm{N}(2)-\mathrm{Mn}(1)-\mathrm{N}(4)$ & $85.19(5)$ \\
$\mathrm{N}(9)-\mathrm{C}(27)$ & $1.294(2)$ & $\mathrm{C}(1)-\mathrm{N}(1)-\mathrm{Mn}(1)$ & $125.75(11)$ \\
$\mathrm{N}(9)-\mathrm{C}(28)$ & $1.318(2)$ & $\mathrm{C}(5)-\mathrm{N}(1)-\mathrm{Mn}(1)$ & $115.56(11)$ \\
$\mathrm{N}(10)-\mathrm{C}(28)$ & $1.151(2)$ & $\mathrm{C}(27)-\mathrm{N}(8)-\mathrm{Mn}(1)$ & $163.57(15)$ \\
\hline & & &
\end{tabular}

The packing in the unit cell is based on intermolecular hydrogen bonding and $\pi-\pi$ stacking interactions. Cooperation between $\pi-\pi$ stacking interactions of phen rings of adjacent molecules and an extensive series of weak $\mathrm{C}-\mathrm{H} \cdots \mathrm{N}_{\text {(dca) }}$ hydrogen bonds (Table 9) between neighbouring molecules further stabilize the structure and form an extended three-dimensional network (Manson, Brown et al. 2013). 
Table 9. Hydrogen-bond geometry for $\mathbf{3}\left(\AA{ }^{\circ}{ }^{\circ}\right)$

\begin{tabular}{lllll}
\hline$D-\mathrm{H} \cdots A$ & $D-\mathrm{H}$ & $\mathrm{H} \cdots A$ & $D \cdots A$ & $D-\mathrm{H} \cdots A$ \\
\hline $\mathrm{C} 1-\mathrm{H} 1 \cdots \mathrm{N}^{1}$ & 0.95 & 2.516 & 3.372 & 150 \\
$\mathrm{C} 3-\mathrm{H} 3 \cdots \mathrm{N}^{\mathrm{ii}}$ & 0.951 & 2.567 & 3.473 & 159.6 \\
$\mathrm{C} 20-\mathrm{H} 20 \cdots \mathrm{N} 7^{\mathrm{iii}}$ & 0.95 & 2.708 & 3.292 & 120.4 \\
$\mathrm{C} 21-\mathrm{H} 21 \cdots \mathrm{N} 7^{\mathrm{iv}}$ & 0.95 & 2.567 & 3.224 & 126.5 \\
$\mathrm{C} 10-\mathrm{H} 10 \cdots \mathrm{N} 9^{\mathrm{v}}$ & 0.95 & 2.657 & 3.439 & 140 \\
$\mathrm{C} 8-\mathrm{H} 8 \cdots \mathrm{N} 10^{\text {vi }}$ & 0.951 & 2.406 & 3.336 & 165.8 \\
$\mathrm{C} 12-\mathrm{H} 12 \cdots \mathrm{N} 5^{\text {vii }}$ & 0.949 & 2.662 & 3.546 & 155.1
\end{tabular}

i) $1-x, 1-y, 1-z$; ii) $2-x, 1-y, 1-z$; iii) -1+x,1.5-y,-1/2+z; iv) $-1+x, 1.5-y,-1 / 2+z$; v) $x, 1.5-y,-1 / 2+z$; vi) $-1+\mathrm{x}, 1.5-\mathrm{y}, 1 / 2+\mathrm{z} ;$ vii) $\quad-1+\mathrm{x}, \mathrm{y}, \mathrm{z}$

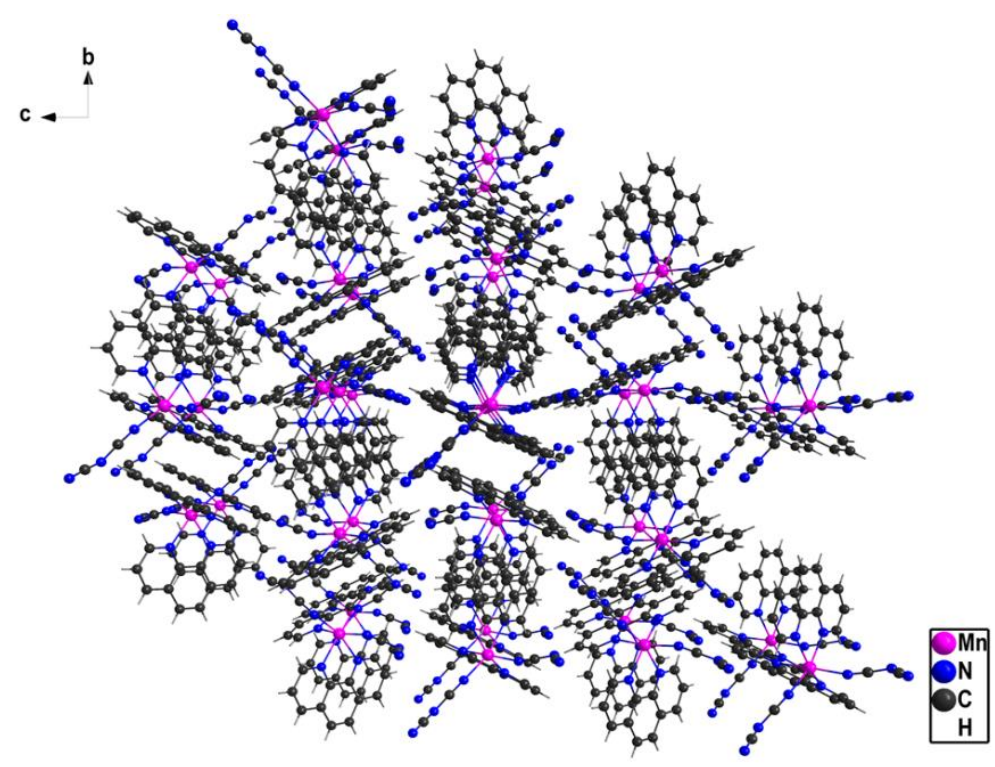

Figure 6. Packing diagram of $\mathbf{3}$ seen along the crystallographic a-axis

\subsection{Magnetic Susceptibility}

The magnetic moments of the Mn(II) complexes (Table 10) 1, 2 and $\mathbf{3}$ are 5.86, 5.83 and 5.92 B.M., respectively. These values are consistent with high spin $\left(\mathrm{d}^{5}\right)$ octahedral geometry.

Table 10. Magnetic moments of the complexes

\begin{tabular}{cccccc}
\hline Compound & $\begin{array}{c}\text { Mass } \\
\text { susceptibility } \\
\left(x_{\mathrm{g}}\right) \times 10^{-6}\end{array}$ & $\begin{array}{c}\text { Molar } \\
\text { susceptibility } \\
\left(x_{\mathrm{m}}\right) \times 10^{-6}\end{array}$ & $\begin{array}{c}\text { Susceptibility of } \\
\text { ligand } \\
\left(x_{\mathrm{L}}\right) \times 10^{-6}\end{array}$ & $x_{\mathrm{A}}$ & $\begin{array}{c}\text { Magnetic } \\
\text { moment } \\
\left(\mu_{\text {eff }}\right) \text { B.M. }\end{array}$ \\
\hline $\begin{array}{c}{\left[\mathrm{Mn}(\mathrm{Phen})_{2}\left(\mathrm{NO}_{3}\right)_{2}\right]} \\
(\mathbf{1})\end{array}$ & 23.33 & 13868.00 & -293.80 & 14162.60 & 5.86 \\
{$\left[\mathrm{Mn}(\mathrm{Phen})_{2}\left(\mathrm{~N}_{3}\right)_{2}\right](\mathbf{2})$} & 27.48 & 13725.90 & -282.02 & 14007.80 & 5.83 \\
{$\left[\mathrm{Mn}(\mathrm{Phen})_{2}(\mathrm{dca})_{2}\right](\mathbf{3})$} & 25.79 & 14117.30 & -310.20 & 14427.50 & 5.92 \\
\hline
\end{tabular}

\subsection{IR Spectroscopy}

The relevant absorption bands in the IR spectra of the ligands and the complexes are summarized in Table 11. In the spectrum of the phen ligand, the absorption bands at 1586 and $1501 \mathrm{~cm}^{-1}$ assigned to $v_{(\mathrm{C}=\mathrm{N})}$ and $v_{(\mathrm{C}=\mathrm{C})}$ stretching vibrations, respectively, are shifted in the complexes to $1580 \mathrm{~cm}^{-1}$ and $1521 \mathrm{~cm}^{-1}$ for $1,1513 \mathrm{~cm}^{-1}$ and $1413 \mathrm{~cm}^{-1}$ for $2,1580 \mathrm{~cm}^{-1}$ and $1515 \mathrm{~cm}^{-1}$ for 3, respectively. These shifts indicate the participation of the $\mathrm{C}=\mathrm{N}$ of phen in bonding (Yanick Gaelle, Ondoh Agwara et al. 2017). The strong absorption band at $2229 \mathrm{~cm}^{-1}$ in the spectrum of dca ligand, assigned to the $v_{(\mathrm{C} \equiv N)}$ is shifted 
to $2209 \mathrm{~cm}^{-1}$ in 3 . The strong absorption band at $2105 \mathrm{~cm}^{-1}$ in the spectrum of the azide ligand, assigned to the asymmetric stretching vibration $v_{(\mathrm{N} 3)}$ of the azide is shifted to $2040 \mathrm{~cm}^{-1}$ in 2, indicating terminal coordination of the azide to the metal ion (Yanick Gaelle, Ondoh Agwara et al. 2017). The new bands at 550, 551 and $557 \mathrm{~cm}^{-1}$ in the complexes indicate the presence of Mn-N bonding between the metal and the nitrogen atoms of phen, dca and the azide.

Table 11. Selected IR absorption bands $\left(\mathrm{cm}^{-1}\right)$ of the ligands and their metal complexes

\begin{tabular}{lcccccccc}
\hline Compound & $v_{(\mathrm{C}=\mathrm{N})}$ & $v_{(\mathrm{C}-\mathrm{N})}$ & $v_{(\mathrm{C}=\mathrm{C})}$ & $v_{(\mathrm{C}=\mathrm{N})}$ & $v_{(\mathrm{N}=\mathrm{N}=\mathrm{N})}$ & $v_{(\mathrm{M}-\mathrm{N})}$ & $v_{(\mathrm{N}-\mathrm{O})}$ & $v_{(\mathrm{Mn}-\mathrm{O})}$ \\
\hline $\mathrm{N}_{3}$ & & & & & $2105 \mathrm{vs}$ & & & \\
$\mathrm{dca}$ & & $1338 \mathrm{~s}$ & & $2229 \mathrm{~s}$ & & & & \\
Phen & $1587 \mathrm{~s}$ & & $1501 \mathrm{vs}$ & & & & & \\
{$\left[\mathrm{Mn}(\mathrm{Phen})_{2}(\mathrm{dca})_{2}\right]$} & $1580 \mathrm{~s}$ & $1515 \mathrm{vs}$ & $2209 \mathrm{~s}$ & & $557 \mathrm{~m}$ & & \\
{$\left[\mathrm{Mn}(\mathrm{Phen})_{2}\left(\mathrm{~N}_{3}\right)_{2}\right]$} & $1513 \mathrm{~s}$ & $1514 \mathrm{~s}$ & & $2040 \mathrm{vs}$ & $551 \mathrm{~m}$ & & \\
{$\left[\mathrm{Mn}(\mathrm{Phen})_{2}\left(\mathrm{NO}_{3}\right)_{2}\right]$} & 1580 & 1521 & & & 550 & 1305 & 1750 \\
\hline
\end{tabular}

$\mathrm{Br}=$ broad, s=strong, vs=very strong, $\mathrm{m}=$ medium, $\mathrm{w}=$ weak.

\subsection{Thermal Analysis}

The thermal decomposition behaviour of compounds $\mathbf{1}$ and $\mathbf{3}$ have been investigated by DTA-TG under an inert atmosphere at a heating rate of $10{ }^{\circ} \mathrm{C} \mathrm{min}{ }^{-1}$ from $30{ }^{\circ} \mathrm{C}$ to $900{ }^{\circ} \mathrm{C}$. The TG curve of complex 1 (Fig. 7) shows that it is stable up to $300{ }^{\circ} \mathrm{C}$. The first and major decomposition step is from 300 to $370{ }^{\circ} \mathrm{C}$ with a mass loss of $48.61 \%$ is attributed to the decomposition of one phenanthroline ring and one nitrate into some solid and a mixture of gaseous products. This step corresponds to a sharp and exothermic DTA peak at $370{ }^{\circ} \mathrm{C}$. The second and third stages from $380-$ $720{ }^{\circ} \mathrm{C}$ and $730-900{ }^{\circ} \mathrm{C}$ are weak mass loss processes considered to be further decomposition of the second nitrate with mass loss of $10.38 \%$ (calculated $11.49 \%$ ). These two stages correspond to two exothermic peaks, one broad and one shallow in the DTA curve with peak temperatures $480{ }^{\circ} \mathrm{C}$ and $880^{\circ} \mathrm{C}$, respectively. The residual mass $(41 \%)$ is probably composed of $\mathrm{Mn}$ and nitrogen in a carbon residue.

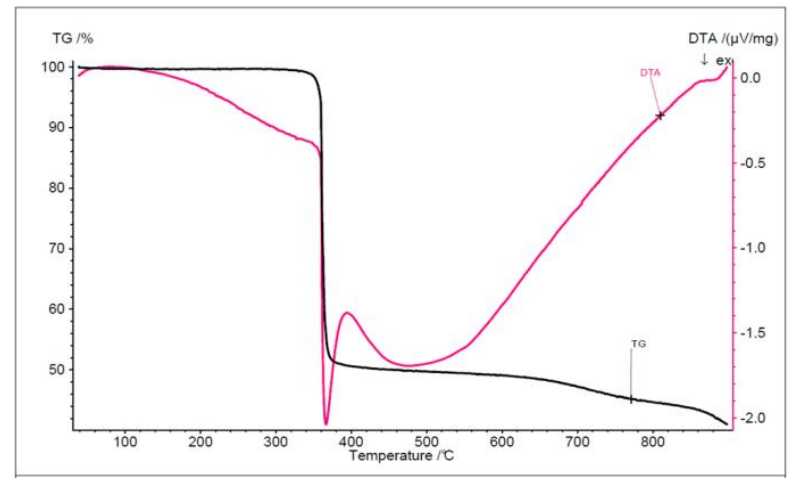

(a)

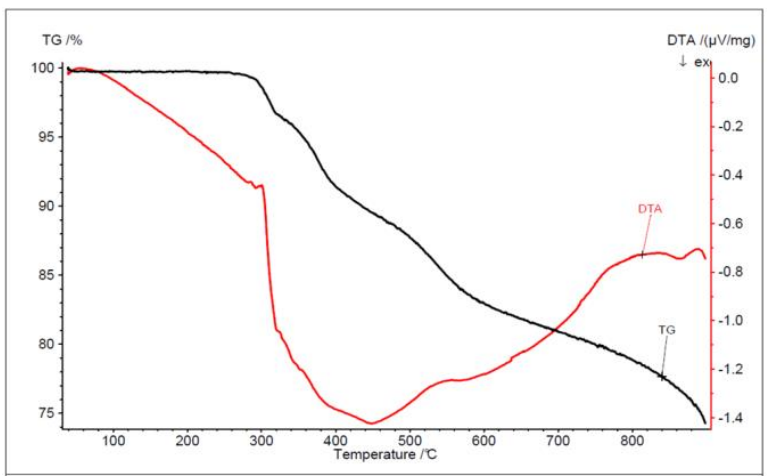

(b)

Figure 7. TG-DTA Curves of (a) 1 and (b) 3

The TG curve of complex 3 (Figure 7) shows that it stable up to $320^{\circ} \mathrm{C}$. The first decomposition step is endothermic, as shown on the DTA curve, followed by a series of decomposition steps from 330 to $600{ }^{\circ} \mathrm{C}$ with a cumulative mass loss of $17.10 \%$. This is attributed to partial decomposition of the solid. This corresponds to a broad exothermic peak in the DTA centred at $450^{\circ} \mathrm{C}$. The last decomposition step from 600 to $900^{\circ} \mathrm{C}$ is another weak mass loss step $8.56 \%$, considered to be further decomposition of the product. The residual mass is $74.34 \%$ indicating high carbon content.

\subsection{Antimicrobial Studies}

The starting materials, the complexes, the reference antibiotic (amoxicillin, ciprofloxacin) and antifungal agents (fluconazole, Cloxacillin) were evaluated against some selected microbial pathogens (twenty bacteria and four fungi strains). The susceptibility of the bacteria and fungi strains towards these compounds was judged by measuring the growth 
inhibition diameter. The diameter of the zone of inhibition (IZ, $\mathrm{mm}$ ) was used to compare the antimicrobial activity of the test compound with that of the reference antibiotic and antifungal. Compounds which showed significant activities (IZ > 6 $\mathrm{mm}$ ) were used for the minimum inhibitory concentration (MIC) test. The MIC values are presented in histograms (Fig. 9 and 10); (MIC $>500 \mu \mathrm{g} / \mathrm{mL}$ poor activity; $250<\mathrm{MIC}>125 \mu \mathrm{g} / \mathrm{mL}$ moderate activity; $62.5<\mathrm{MIC}>31.25 \mu \mathrm{g} / \mathrm{mL}$ good activity; MIC $<31.25 \mu \mathrm{g} / \mathrm{mL}$ very good activity). While the simple metal salt $\mathrm{Mn}\left(\mathrm{NO}_{3}\right)_{2}$ and the co-ligands $\mathrm{N}_{3}{ }^{-}$and dca, were not able to effectively reduce the bacterial and fungal cell proliferation, 1,10-phen exhibited good inhibitory capability which is in agreement with results obtained from other studies (Gandra, Mc Carron et al. 2017, Yanick Gaelle, Ondoh Agwara et al. 2017). Complex 1 possesses very good activity against most of the bacteria species with MIC values 15.625 and 31.25 $\mu \mathrm{g} / \mathrm{mL}$, while complexes 2 and 3 are very active against the fungi species with MIC values in the range 7.8-15.6 $\mu \mathrm{g} / \mathrm{mL}$. However, all of these complexes displayed comparable as well as poor antibacterial activities compared to the standard antibacterials (amoxicillin, ciprofloxacin) but higher antifungal activities as compared to the antifungals (fluconazole, Cloxacillin). These activities are comparable to literature reports (Coyle, Kavanagh et al. 2003, Gandra, Mc Carron et al. 2017). Complex 1 was the most active and it showed very good activity (MIC $15.625 \mu \mathrm{g} / \mathrm{mL}$ ) against the bacteria species Staphylococcus aureus BAA917, Salmonella enterica NR4311, Enterococcus fecalis ATCC51219 and Mycobacterium smegmatis. The complexes exhibited very good activity against the fungi species Candida krusei, Candida parasilosis and Candida albicans, as compared to the reference antifungal and also showed good antibacterial activity comparable to the reference antibiotic. For example, the $\left.\left[\mathrm{Mn}(\mathrm{Phen})_{2}\left(\mathrm{NO}_{3}\right)_{2}\right)\right]$ complex (1) showed greater activity against streptococcus pneumonae compared to the ligands, the metal salt and the reference antibiotic demonstrating that the chelates are much superior antimicrobial agents. The most active compound (1) showed very good activity (MIC $15.625 \mu \mathrm{g} / \mathrm{mL}$ ) against the bacteria species Staphylococcus aureus BAA917, Salmonella enterica NR4311, Enterococcus fecalis ATCC51219 and Mycobacterium smegmatis.

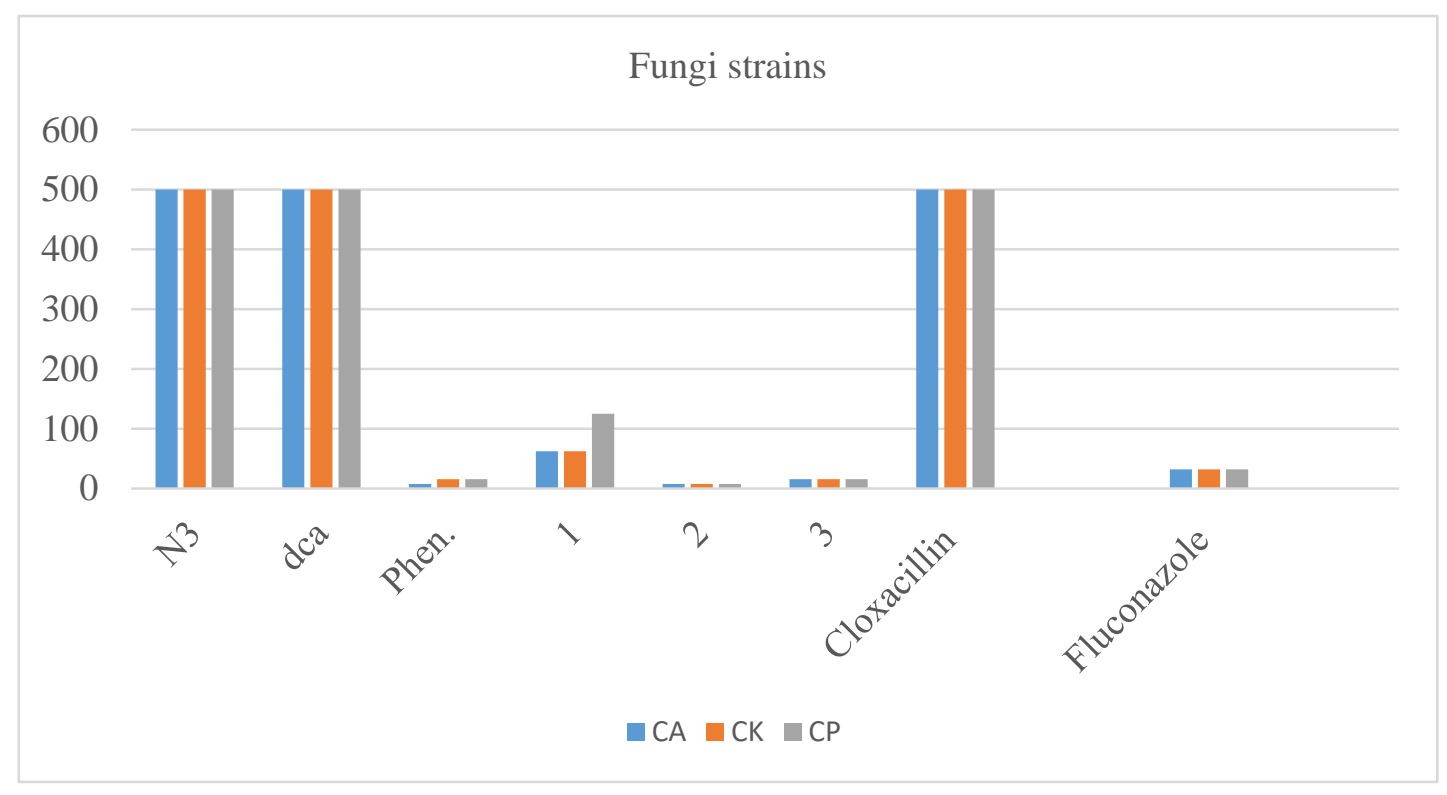

Figure 8. Histogram of MIC against yeast species 


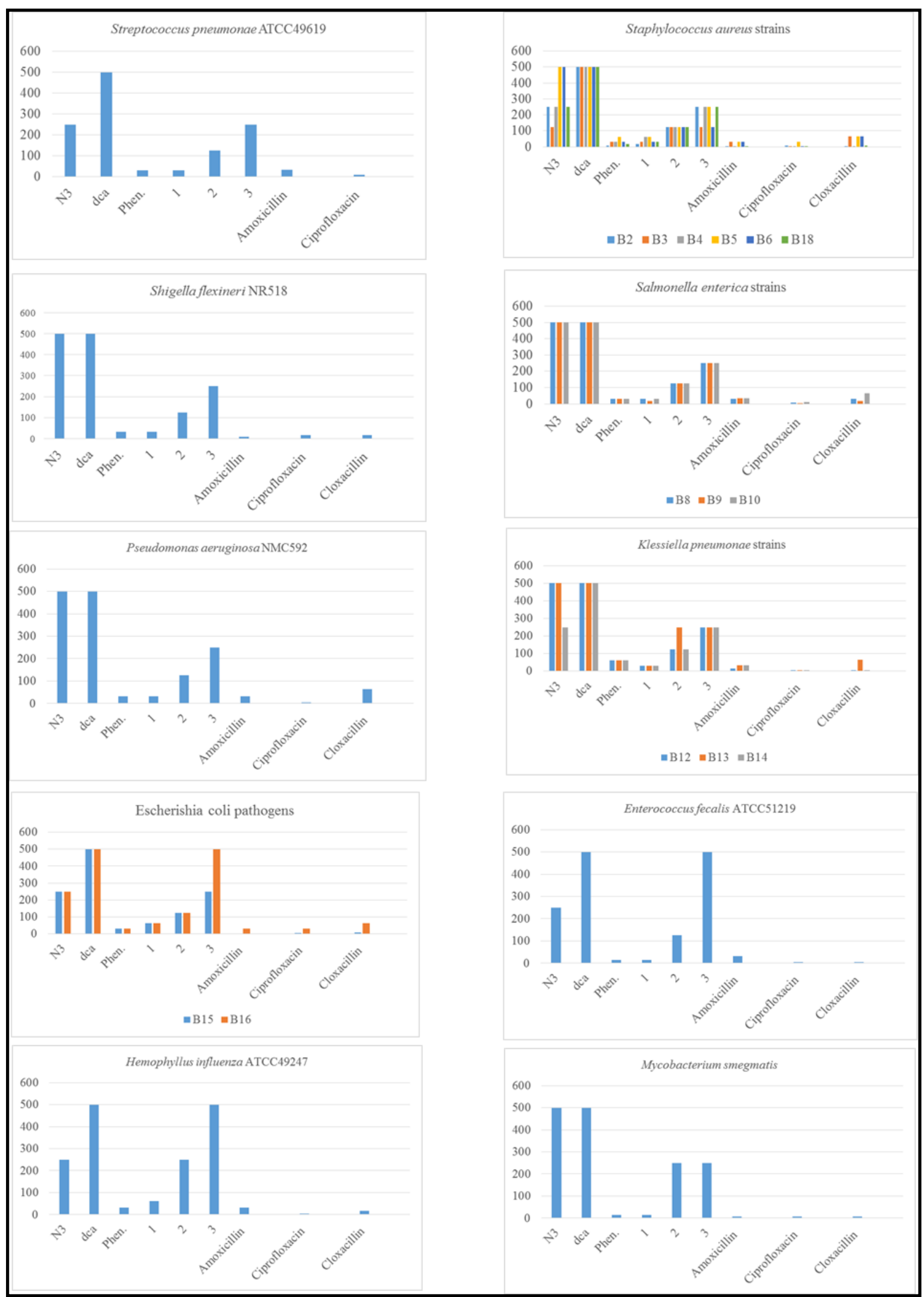

Figure 9. Histogram of MIC against bacteria species

The increased activity of the metal complexes can be explained based on the chelation theory and overtones concept. 
This indicates that reaction of metal ions with the ligands plays an important role in enhancing its antimicrobial activity. This enhancement of the metal complex activity can also be explained on the basis of chelation theory. Chelation reduces the polarity of the metal atom mainly because of partial sharing of its positive charge with the donor groups and possible $\pi$-electron delocalization within the whole chelate ring. Such a chelation also enhances the lipophilic character of the central metal atom, which subsequently favours its permeation through the lipid layers of the cell membrane and the blocking of the metal binding sites on enzymes of microorganism (Chohan, Munawar et al. 2001). The overall positive results of the antimicrobial screening against the twenty-three pathogens suggest that the complexes have a broad spectrum of activity and may represent a good candidate as an antimicrobial agent.

\section{Conclusion}

Manganese(II) complexes $\left[\mathrm{Mn}(\mathrm{Phen})_{2}\left(\mathrm{NO}_{3}\right)_{2}\right]$ (1), [Mn(Phen $\left.\left.)_{2}\left(\mathrm{~N}_{3}\right)_{2}\right)\right]$ (2), and $\left.\left[\mathrm{Mn}(\mathrm{Phen})_{2}(\mathrm{dca})_{2}\right)\right]$ (3) have been synthesized. Distorted octahedral geometries were confirmed through single-crystal X-ray crystallographic techniques. Cooperation between $\mathrm{C}-\mathrm{H} \cdots \mathrm{O}$ or $\mathrm{C}-\mathrm{H} \cdots \mathrm{N}$ hydrogen bonds between adjacent phen ligands, and $\pi-\pi$ stacking interactions stabilize the structures and assemble them into interesting 3D supramolecular structures. The magnetic moments of the $\mathrm{Mn}(\mathrm{II})$ complexes were found to be consistent with high spin $\left(\mathrm{d}^{5}\right)$ octahedral geometry. Thermal analyses of the complexes $\mathbf{1}$ and $\mathbf{3}$ under inert conditions indicate that they are stable up to $300^{\circ} \mathrm{C}$. A high residual $(>40 \%)$ indicates high carbon content in the residue. The complexes exhibited poor antibacterial activities as compared to standard antibacterials (amoxicillin, ciprofloxacin) but very good activity against the fungi species Candida krusei, Candida parasilosis and Candida albicans, as compared to the reference antifungals (fluconazole, Cloxacillin). This high antifungal activity indicates the potential of the complexes as alternative antifungal agents to fluconazole. However, additional and profound in vitro antimicrobial studies mainly in relation to the elucidation of the mechanism of growth of inhibition and toxicity of the complex is on-going.

\section{Competing Interests}

The authors declare that there is no conflict of interests regarding the publication of this paper.

\section{Acknowledgments}

The authors acknowledge Dr. Kevin Klausmeyer, Department of Chemistry and Biochemistry Baylor University, USA for assistance with one of the crystal structures.

\section{References}

Adhikary, C., \& Koner, S. (2010). Structural and magnetic studies on copper(II) azido complexes. Coord. Chem. Rev., 254(23-24), 2933-2958. http://dx.doi.org/10.1016/j.ccr.2010.06.001.

Agwara, M. O., Ndifon, P. T., Ndosiri, N. B., Paboudam, A. G., Yufanyi, D. M., \& Mohamadou, A. (2010). Synthesis, Characterisation and Antimicrobial Activities of Cobalt(II), Copper(II) and Zinc(II) Mixed-Ligand Complexes Containing 1,10-Phenanthroline and 2,2'-Bipyridine. Bull. Chem. Soc. Ethiop., 24(3), 383-389.

Aljahdali, M., \& El-Sherif, A. A. (2013). Synthesis, characterization, molecular modeling and biological activity of mixed ligand complexes of $\mathrm{Cu}(\mathrm{II}), \mathrm{Ni}(\mathrm{II})$ and $\mathrm{Co}(\mathrm{II})$ based on 1,10-phenanthroline and novel thiosemicarbazone. Inorg. Chim. Acta, 407, 58-68. http://dx.doi.org/10.1016/j.ica.2013.06.040.

Allan, J. R., Brown D. H., \& Lappin, M. (1970). Transition Metal Halide Complexes of Hexamethylenetetramine. J. Inorg. Nucl. Chem., 32, 2287-2292.

Amah, C., Ondoh, A. M., Yufanyi, D. M., \& Gaelle, D. S. Y. (2015). Synthesis, Crystal Structure and Antimicrobial Properties of an Anhydrous Copper(II) Complex of Pyridine-2-Carboxylic Acid Inter. J. Chem., 7(1), 10-20. http://dx.doi.org/10.5539/ijc.v7n1p10.

Batten, S. R., \& Murray, K. S. (2003). Structure and magnetism of coordination polymers containing dicyanamide and tricyanomethanide. Coord. Chem. Rev., 246(1-2), 103-130. 10.1016/S0010-8545(03)00119-X.

Bencini, A., \& Lippolis, V. (2010). 1,10-Phenanthroline: A versatile building block for the construction of ligands for various purposes. Coord. Chem. Rev., 254(17-18), 2096-2180. http://dx.doi.org/10.1016/j.ccr.2010.04.008.

Berghe, D. V., \& Vlietinck, A. (1991). Screening methods for antibacterial and antiviral agents from higher plants Methods in plant biochemistry: Volume 6. Assays for bioactivity. K. Hostettmann. London, Academic Press Ltd.: $\mathrm{xi}+360 \mathrm{pp}$.

Beyth, N., Houri-Haddad, Y., Domb, A., Khan, W., \& Hazan, R. (2015). Alternative Antimicrobial Approach: Nano-Antimicrobial Materials. J. Evid. Based Complementary Altern. Med. 2015: 16.

https://doi.org/10.1155/2015/246012. 
Bruker (2004). APEX2, SAINT-Plus and XPREP. Madison, Wisconsin, USA., Bruker AXS Inc.

Čechová, D., Martišková, A., \& Moncol, J. (2014). Structure of cis-dichlorobis(1,10-phenanthroline)manganese(II) and cis-dichlorobis(2,2’-bipyridine)manganese(II). Acta Chim. Slovaca, 7(1), 15. https://doi.org/10.2478/acs-2014-0003.

Chen, Z. L., Jiang, C. F., Yan, W. H., Liang, F. P., \& Batten, S. R. (2009). Three-Dimensional Metal Azide Coordination Polymers with Amino Carboxylate Coligands, Synthesis, Structure, and Magnetic Properties. Inorg. Chem., 48, 4674-4684. http://dx.doi.org/10.1021/ic802026n.

Chohan, Z. H., Munawar, A., \& Supuran, C. T. (2001). Transition Metal Ion Complexes of Schiff-bases. Synthesis, Characterization and Antibacterial Properties. Metal-Based Drugs, 8(3), 137-143. https://dx.doi.org/10.1155/mbd.2001.137.

Colak, A. T., Oztopcu-Vatan, P,. Colak, F., Akduman, D., Kabadere, S., \& Uyar, R. (2013). Syntheses, characterization, antimicrobial and cytotoxic activities of pyridine-2,5-dicarboxylate complexes with 1,10-phenanthroline. J. Trace Elements in Medicine and Biology, 27(4), 295-301. https://dx.doi.org/10.1016/j.jtemb.2013.04.005.

Coyle, B., Kavanagh, K., McCann, M., Devereux, M., \& Geraghty, M. (2003). Mode of anti-fungal activity of 1,10-phenanthroline and its $\mathrm{Cu}(\mathrm{II}), \mathrm{Mn}(\mathrm{II})$ and $\mathrm{Ag}(\mathrm{I})$ complexes. Biometals 16(2), 321-329. https://dx.doi.org/10.1023/a:1020695923788.

Farrugia, L. (1997). ORTEP-3 for Windows - a version of ORTEP-III with a Graphical User Interface (GUI). J. Appl. Crystallog., 30(5 Part 1), 565. https://dx.doi.org 10.1107/S0021889897003117.

Gaëlle, D. S. Y., Yufanyi, D. M., Jagan, R., \& Agwara, M. O. (2016). Synthesis, characterisation and antimicrobial properties of cobalt(II) and cobalt(III) complexes derived from 1,10-phenanthroline with nitrate and azide co-ligands. Cogent Chem., 2, 1253201. https://dx.doi.org/10.1080/23312009.2016.1253201.

Gandra, R. M., Mc Carron, P., Fernandes, M. F., Ramos, L. S., Mello, T. P., Aor, A. C., ... Santos, A. L. S. (2017). Antifungal Potential of Copper(II), Manganese(II) and Silver(I) 1,10-Phenanthroline Chelates Against Multidrug-Resistant Fungal Species Forming the Candida haemulonii Complex: Impact on the Planktonic and Biofilm Lifestyles. Frontiers in Microbiology, 8(1257). https://dx.doi.org/10.3389/fmicb.2017.01257.

Hu, L. X., \& Zhang, B. S. (2016). Aqua(4-bromobenzoato-kO)bis(1,10-phenanthroline-k $\left.{ }^{2} \mathrm{~N}, \mathrm{~N}^{\prime}\right)$ manganese(II) 4-bromobenzoate dihydrate. IUCrData, I(5), x160833. https://dx.doi.org/10.1107/S2414314616008336.

Janiak, C. (2000). A critical account on $\pi-\pi$ stacking in metal complexes with aromatic nitrogen-containing ligands. $J$. Chem. Soc., Dalton Trans., (21), 3885-3896. https://dx.doi.org/10.1039/B003010O.

Jennifer, S. J., \& Muthiah, P. T. (2014). Mixed-ligand complexes of $\mathrm{Ca}(\mathrm{II}), \mathrm{Ba}(\mathrm{II}), \mathrm{Mn}(\mathrm{II})$ and $\mathrm{Pd}(\mathrm{II})$ with 1,10-phenanthroline and 5-chloro thiophene 2-carboxylic acid ligands: Role of hybrid carboxylate-water clusters and ligands of crystallisation in building up of supramolecular architectures. Inorg. Chim. Acta, 414, 170-180. https://dx.doi.org/10.1016/j.ica.2014.01.053.

Kani, I., Atlier, Ö., \& Güven, K. (2016). Mn(II) complexes with bipyridine, phenanthroline and benzoic acid: Biological and catalase-like activity. J. Chem. Sci., 128(4), 523-536. https://dx.doi.org/10.1007/s12039-016-1050-z.

Lazari, G., Stamatatos, T. C., Raptopoulou, C. P., Psycharis, V., Pissas, M., Perlepes, S. P., \& Boudalis, A. K. (2009). A metamagnetic 2D copper(II)-azide complex with 1D ferromagnetism and a hysteretic spin-flop transition. Dalton Trans.: 3215-3221. https://dx.doi.org/10.1039/b823423j.

Ma, C., Wang, W., Zhu, H., Chen, C., \& Liu, Q. (2001). Phenanthroline-manganese inclusion complexes of dicarboxylic acid containing extensive hydrogen-bonding interactions. Inorg. Chem. Commun. 4(12), 730-733. https://doi.org/10.1016/S1387-7003(01)00312-4.

Manson, J. L., Brown, C. M., Huang, Q., Schlueter, J. A., Lancaster, T., Blundell, S. J. ... Pratt, F. L. (2013). $\mathrm{Mn}(\mathrm{dca})_{2}$ (o-phen) $\{$ dca=dicyanamide; o-phen=1,10-phenanthroline $\}$ : Long-range magnetic order in a low-dimensional Mn-dca polymer. Polyhedron, 52, 679-688. https://doi.org/10.1016/j.poly.2012.07.087.

Masárová, P., \& Moncol, J. (2016). Crystal structures of $\left[\mathrm{M}\left(\mathrm{N}_{3}\right)_{2}(\mathrm{phen})_{2}\right]$ compounds, $\mathrm{M}=\mathrm{Mn}, \mathrm{Co}$ or $\mathrm{Cu}$ and phen $=$ 1,10-phenanthroline. Acta Chim. Slovaca, 9(2), 152. https://doi.org/10.1515/acs-2016-0026.

McCann, M., Geraghty, M., Devereux, M., O'Shea, D., Mason, J., \& O'Sullivan, L. (2000). Insights into the mode of action of the anti-candida activity of 1,10-phenanthroline and its metal chelates. Metal Based Drugs, 7(4), 185-193.

Mohamadou, A., van Albada, G. A., Kooijman, H., Wieczorek, B., Spek, A. L., \& Reedijk, J. (2003). The binding mode 
of the ambidentate ligand dicyanamide to transition metal ions can be tuned by bisimidazoline ligands with H-bonding donor property at the rear side of the ligand. New J. Chem., 27(6), 983-988. https://dx.doi.org/10.1039/B212059C

Nagase, K., Yokobayashi, H., \& Sone, K. (1976). Color and Structural Changes of Bis(hexamethylenetetramine)cobalt(II) and Nickel(II) Complexes in the Course of Thermal Dehydration in the Solid State. Bulletin of the Chemical Society of Japan, 49(6), 1563-1567.

Pook, N. P., Hentrich, P., \& Gjikaj, M. (2015). Crystal structure of bis[tris(1,10-phenanthroline $\left.\left.\mathrm{k}^{2} \mathrm{~N}, \mathrm{~N}^{\prime}\right) \operatorname{cobalt(II)}\right]$ tetranitrate N,N'-(1,4-phenylenedicarbonyl)diglycine solvate octahydrate. Acta Cryst. E, 71(8), 910-914. https://dx.doi.org/10.1107/S2056989015013006.

Saphu, W., Chanthee, S., Chainok, K., Harding, D. J., \& Pakawatchai, C. (2012). trans-Bis(nitrato-kO)bis(1,10-phenanthroline-k $\left.{ }^{2} \mathrm{~N}, \mathrm{~N}^{\prime}\right)$ manganese(II). Acta Cryst. E 68(8), m1026. https://dx.doi.org/10.1107/S1600536812029364.

Sheldrick, G. M. (1997). S\{HELX\}97. \{P\}rograms for crystal structure analysis.

Shen, Z., Zuo, J. L., Chinnakali, K., Fun, H. K., \& You, X. Z. (1999). Diazidobis(1,10-phenanthroline-N,N')manganese(II). Acta Cryst. C, 55(6), 901-903. https://dx.doi.org/10.1107/S010827019900181X.

Sidjui, L. S., Toghueo, R. M. K., Zeuko`o, E. M., Mbouna, C. D. J., Leddet, V. M., Herbette, G., ... Folefoc, G. N. (2016). Antibacterial Activity of the Crude Extracts, Fractions and Compounds from the Stem Barks of Jacaranda mimosifolia and Kigelia africana (Bignoniaceae). Pharmacologia, 7(1), 22-31. https://dx.doi.org/10.5567/pharmacologia.2016.22.31

Spellberg, B., Guidos, R., Gilbert, D., Bradley, J., Boucher, H. W., Scheld, W. M., ... Edwards, A. The Infectious Diseases Society of (2008). The Epidemic of Antibiotic-Resistant Infections: A Call to Action for the Medical Community from the Infectious Diseases Society of America. Clinical Infectious Diseases, 46(2), 155-164. https://dx.doi.org/10.1086/524891

Sun, J., Tong, X., \& Xu, H. (2010). Synthesis, structures and properties of $\mathrm{Cu}$ and $\mathrm{Cd}$ complexes with 1,10-phenanthroline. Inorg. Chem. Commun. 13(5), 645-648. https://dx.doi.org/10.1016/j.inoche.2010.03.009.

Tabong, C. D., Yufanyi, D. M., Paboudam, A. G., Nono, K. N., Eni, D. B., \& Agwara, M. O. (2016). Synthesis, Crystal Structure, and Antimicrobial Properties of [Diaquabis(hexamethylenetetramine)diisothiocyanato-kN]nickel(II) Complex. Advances in Chemistry 2016, Article ID 5049718: 8 pages. https://dx.doi.org/10.1155/2016/5049718.

Wang, Z. M., Luo, J., Sun, B. W., Yan, C. H., Liao, C. S., \& Gao, S. (2000).

cis-Bis(dicyanamido)bis(1,10-phenanthroline)manganese(II) and cis-bis(dicyanamido)bis(1,10-phenanthroline)zinc(II). Acta Cryst. C 56(6), e242-e244. https://dx.doi.org/10.1107/S0108270100006132.

Weinstein, R. A., \& Fridkin, S. K. (2003). Routine Cycling of Antimicrobial Agents as an Infection-Control Measure. Clinical Infectious Diseases, 36(11), 1438-1444. https://dx.doi.org/10.1086/375082.

WHO (2014). Antimicrobial resistance. Global report on surveillance Geneva, Switzerland.

Wieghardt, K. (1989). The Active Sites in Manganese-Containing Metalloproteins and Inorganic Model Complexes. Angew. Chem. Int. Ed., 28(9), 1153-1172. https://dx.doi.org/10.1002/anie.198911531.

Yanick, G. D. S., Ondoh, A. M., Yufanyi, D. M., Nenwa, J., \& Jagan, R. (2017). Crystal structure and antimicrobial properties of a copper(II) complex with 1,10-phenanthroline and azide co-ligand. Inorg. and Nano-Metal Chem., 47(4), 618-625. https://dx.doi.org/10.1080/15533174.2016.1212220

Zhang, X., Chen, F., Wang, W., Chen, C., \& Liu, Q. (2002).

Aqua(chloroacetato)bis(1,10-phenanthroline-N,N')manganese(II) perchlorate. Acta Cryst. E 58(7), m360-m362. https://dx.doi.org/10.1107/S1600536802010899

\section{Copyrights}

Copyright for this article is retained by the author(s), with first publication rights granted to the journal.

This is an open-access article distributed under the terms and conditions of the Creative Commons Attribution license (http://creativecommons.org/licenses/by/4.0/). 